\title{
Dialética e o Método da Ética em Aristóteles
}

For the last decades, the thesis according to which dialectic provides the core methodological standard for Aristotle's practical philosophy has had wide acceptance. This thesis has been associated to the much-discussed methodological passage of Nicomachean Ethics VII 1, 1145b27. As a matter of fact, the traditional reading of that passage finds in it a procedure that is based on the survey of aporiai that have been drawn from a set of endoxa or "reputable opinions". As the procedure so understood is thoroughly focused on endoxa and in virtue of its diaporematic approach, it can be related to dialectic as it is discussed in the Topics. In this paper, I intend to address the limitations of the traditional interpretation and put forward an alternative reading for the methodological passage of Nicomachean Ethics VII 1. In the proposed reading, the passage does not have a tight connection with dialectic. From this it does not follow that dialectical procedures play no role in the method of Aristotle's practical philosophy. However, in the proposed reading the passage of NE VII 1 no longer provides the basis for the thesis that such method is to be understood as being fundamentally dialectical in its nature.

A história recente da interpretação do método aristotélico para a filosofia prática está fortemente marcada pela noção de "dialética". Com efeito, no prefácio de The ethics of Aristotle (1900), John Burnet apresentou o que considerava ser um fato até então insuficientemente reconhecido: a Ética Nicomaqueia seria um tratado "inteiramente dialético" (1900, p. v). ${ }^{2}$ Se pôde parecer a Burnet que a importância metodológica da dialética para a filosofia prática era subestimada pelos estudiosos do tema à época da redação de seu trabalho, a mesma impressão não teria sido causada pelos intérpretes das

${ }^{1} \mathrm{O}$ desenvolvimento deste trabalho beneficiou-se de discussões, comentários e críticas de vários colegas. Gostaria, em particular de agradecer a João Carlos Brum Torres, Wellington Almeida, Felipe Weinmann, Marco Zingano, Rodrigo Guerizoli, Anderson Borges, Paulo F. T. Ferreira, Nelson Boeria, Lucas Angioni, Simone Seminara, Fernando Mendonça, Daniel Wolt, Fernando Gazoni, Inara Zanuzzi, Edson Resende, Priscilla Spinelli, Breno Zuppolini, André Luiz Cruz Sousa, Carolina Sanchez, Eduardo Wolf, Flávio Williges, Jaqueline Stefani, José Carlos Baracat Jr. e Daniel Vazquez. O presente trabalho foi realizado com apoio do CNPq, Conselho Nacional de Desenvolvimento Científico e Tecnológico (Processo n ${ }^{\circ}$ 307765/2016-4), tendo contado com apoio da FAPESP, Fundação de Amparo à Pesquisa do Estado de São Paulo (Processo $\mathrm{n}^{\mathrm{o}}$ 2016/09861-7) durante parte de seu desenvolvimento.

${ }^{2}$ Todas as traduções são de minha autoria (tanto dos textos de Aristóteles, quanto da bibliografia secundária em língua estrangeira). 
décadas seguintes. Ainda que poucos tenham sustentado que a dialética qualifique o método da ética aristotélica em sua totalidade ${ }^{3}$, tornou-se comum tomá-la como sendo por excelência o marco metodológico da filosofia prática de Aristóteles. ${ }^{4}$

O ponto de inflexão na história recente da compreensão do método da ética corresponde à publicação em 1961 do muitíssimo influente artigo Tithenai ta phainomena, de G. E. L. Owen. Naquele trabalho, Owen parte da relação entre o discurso metodológico de Aristóteles nos Analíticos e sua prática na Física, concluindo que o método empregado nesse último tratado não é científico no sentido dos Analíticos, mas dialético. No artigo de Owen, desempenha papel fundamental a passagem metodológica de Ética Nicomaqueia VII 1, 1145b2-75, na qual se encontra a descrição de um procedimento que o autor compreende como correspondendo a uma análise conceitual aplicada a endoxa ou "opiniões reputáveis" (1961, p. 85-86). Esse procedimento, tomado como sendo de natureza dialética e contrastado com o método empírico encontrado em trabalhos como Historia Animalium e Meteorologica, formaria o núcleo metodológico de obras como a Física, a Metafísica e, evidentemente, os tratados de ética.

A partir de Owen não mais se constata o cenário descrito por Burnet, sendo posição majoritária a tese segundo a qual a dialética caracteriza o método da ética, se não de toda a filosofia de Aristóteles. Desde a publicação de Tithenai ta phainomena, surgiram variadas interpretações a respeito da natureza e alcance metodológico da dialética ${ }^{6}$ (e, atualmente, está longe de ser consensual a compreensão do chamado "método dialético"

${ }^{3}$ Hardie (1980, pp. 42-43) observou que o próprio Burnet não é inteiramente consistente a esse respeito. A despeito de afirmar no início do prefácio que a Ética Nicomaqueia seria inteiramente dialética, Burnet acaba por admitir que procedimentos de outra natureza têm lugar na ética de Aristóteles (ver Burnet : 1900, p. xliii).

${ }^{4}$ Ver Greenwood (1909. p. 132-133); Ross ([1923]1995, p. 199); Cooper (1986, p. 67-71); Crisp (1991 e 2004); Reeve (1992, p. 34-45; p. ix-x); Irwin (1999, p. 326); Kraut (2006, p. 77); Brown (2009, p. xxii); May (2010, pp. 78-79). Barnes, que emprega a expressão "método dos endoxa" para se referir ao que usualmente se denomina "método dialético", sustenta com base em Ética Eudêmia I 6, 1216b26-28 que, além de tal método, Aristóteles adota o procedimento dia logôn ("por recurso a argumentos"). Os resultados desse procedimento alternativo, no entanto, não poderiam entrar em conflito ou exceder os resultados obtidos pelo método dos endoxa (Barnes : 1980, p. 494-495).

${ }^{5}$ A esse respeito, o contraste entre Owen e Burnet é notável. Enquanto o primeiro toma a passagem de Ética Nicomaqueia VII 1, 1145b2-7 como texto fundamental, o segundo conferelhe relativamente pouca atenção, tomando-o como mera exposição esquemática do método que estaria exposto nos Tópicos (Burnet : 1900, p. 291).

${ }^{6}$ May Sim, na introdução a "From puzzles to principles?", coletânea de trabalhos dedicados à dialética aristotélica, classifica as contribuições contidas na obra em nada menos do que sete grandes campos distintos quanto à natureza da dialética (1999, p. ix-xi). 
como análise conceitual nos termos de Owen). ${ }^{7}$ Permanece, no entanto, prática corrente tomar a passagem metodológica de EN VII 1 como texto central para a compreensão do método da ética, que estaria fundamentalmente assentado em um procedimento de matiz dialético a ser aplicado sobre endoxa.

Nos últimos anos, diversos intérpretes têm apontado as limitações desse modelo interpretativo e novas alternativas têm sido buscadas para a compreensão do método da ética aristotélica. ${ }^{8}$ Este trabalho está em boa medida alinhado a essa tendência. Sem propriamente concentrar o ataque sobre uma ou outra interpretação particular, pretendo apontar problemas que afetam o que considero serem os traços fundamentais da proposta interpretativa geral que se tornou predominante a partir de Owen. Parte importante deste trabalho consistirá em um exame de EN VII 1, 1145b2-7, a partir do qual pretendo mostrar que, se uma leitura bastante direta da passagem favorece o modelo atualmente hegemônico, as consequências de tal leitura criam dificuldades significativas para aquele modelo. Ao fim do texto, pretendo propor uma compreensão alternativa para esse texto fundamental.

\section{A dialética e os Tópicos}

A tese segundo a qual o método da ética é de natureza dialética está, em sua origem, associada a tratado que nos foi transmitido com o título de Tópicos. ${ }^{9}$ Essa obra é dedicada à dialektikê technê ou "arte dialética" e é para ela que nos remete Burnet, afirmando que lá encontraríamos "a justificação teórica do método empregado na Ética” (1900, p. xl).

A arte discutida (e em boa medida desenvolvida) nos Tópicos está associada à prática de debates, o que se reflete na relação etimológica entre a expressão dialektikê technê e o verbo dialegesthai, “dialogar”. Por essa razão, Aristóteles pode afirmar que todos em certa medida tomam parte da dialética. Afinal, "todos, até certo ponto, lançam mão das práticas de examinar [exetazein] e sustentar um argumento" (Retórica I 1, 1354a4-6). Para além, no entanto, da atividade intuitiva da discussão de teses e argumentos, os

\footnotetext{
${ }^{7}$ Ver, por exemplo, Cooper (2009, p. 29, n. 35).

${ }^{8}$ Nos últimos anos, no entanto, tem crescido a tendência de buscar nos Analíticos um marco metodológico alternativo para a compreensão do método da ética. Ver, por exemplo, Natali (2007 e 2010); Salmieri (2009); Karbowski (2015a e 2015b) e Devereux (2015).

${ }^{9}$ Para uma exposição geral do conteúdo e estrutura dos Tópicos, ver Brunschwig : 1967, p. xviiilv e Pereira : 2000, p. 361-369.
} 
Tópicos têm em seu plano de fundo um tipo de debate com características em alguma medida específicas. Trata-se de um debate que, ao ser qualificado como "dialético", ganha uma dimensão algo técnica, associada ao ambiente no qual se desenvolveu a escola de Aristóteles.

É bastante claro que Aristóteles escreve a um leitor até certo ponto familiarizado com tais debates, fazendo uso, inclusive, de um vocabulário técnico à maneira de jargão já estabelecido. O objetivo dos Tópicos seria, então, o de fornecer regras práticas rigorosas para essa atividade, disciplinando o que, até então, permanecia desregrado e fornecendo as diretrizes que levariam ao debate dialético bem-sucedido (100a18-21, 101a28-30). ${ }^{10}$

De tais debates (cujo retrato mais detalhado emerge do livro VIII dos Tópicos) ${ }^{11}$, tomavam parte dois participantes ocupados com um problema cuja formulação admitiria "sim" ou "não" como resposta (101b28-34). A um dos participantes cabia o papel de respondedor e, ao outro, o de questionador. Tendo o primeiro adotado uma posição determinada com relação ao problema proposto, o segundo passava a dirigir-lhe perguntas com o objetivo de fazê-lo aceitar proposições que forneceriam as premissas de um argumento do qual se extrairia idealmente a contradição da tese inicialmente assumida. Alternativamente, o questionador buscaria estabelecer as consequência mais paradoxais possíveis (adoxatata: Top. VIII 4, 159a18-20) da tese adotada pelo respondedor. O objetivo do segundo, por sua vez, era evitar tais resultados, buscando antecipar as consequências de suas respostas para a adoção consistente da tese inicial. ${ }^{12}$

Via de regra, os trabalhos que tomam a dialética como marco metodológico de Aristóteles dão pouca atenção à relação que a arte dialética dos Tópicos tem com esse tipo de debate. Aspectos daquela obra dos quais se busca derivar características fundamentais do método da ética, ganham significação mais singela quando compreendidas à luz dos debates com mira nos quais os Tópicos foram compostos. Caso particularmente notável diz respeito aos endoxa, que são frequentemente tomados como

10 "O objeto dos Tópicos (...) é o de dotar de um método seguro uma atividade até então abandonada à inspiração ou à rotina" (Brunschwig : 1967, p. ix). Sobre a prática pré-existente de debates dialéticos e sua relação com os Tópicos, ver também Moraux (1968, p. 291 ss.) e Smith (1997, p. xx-xi).

${ }^{11}$ Uma exposição pormenorizada de tais debates pode ser encontrada em Moraux (1968). Ver também Brunschwig : 1967, p. xxii-xxxiv e Smith : 1993, p. 340-343; 1997, p. xi-xvi.

${ }^{12}$ Inúmeras passagens dos Tópicos deixam transparecer que Aristóteles tem em vista um debate entre um questionador e um respondedor assim caracterizados. Para exemplos externos ao livro VIII (onde tais passagens abundam), ver 100a18-21, 108a22-31 e 111b32-112a15. 
foco do método da ética. Nos Tópicos, contudo, seu papel está fundamentalmente associado à atividade do questionador, que deve selecionar dentre os endoxa as proposições que serão submetidas à apreciação do respondedor.

O escopo dos endoxa é delimitado como correspondendo às opiniões sustentadas "por todos ou pela maioria ou pelos sábios - ou seja, por todos esses ou pela maioria deles ou pelos mais notáveis e reputados" (Top. I 1, 100b21-23). Uma interpretação de grande aceitação para o traço distintivo dessa delimitação extensional dos endoxa foi proposta por Jonathan Barnes (1980, p. 498-502). Tomando por base o uso ordinário do adjetivo endoxos como qualificativo para o que é de boa reputação, Barnes propôs que se compreendesse endoxa como significando "opiniões reputáveis" ou seja, opiniões que estão, de algum modo, associadas à posse de boa reputação. ${ }^{13}$

Assim, tendo pleno sucesso o questionador, o debate se encerra com o estabelecimento de um argumento cuja conclusão corresponde à contraditória da tese inicialmente assumida pelo respondedor e cujas premissas correspondem a opiniões reputáveis. Trata-se do tipo de argumento que já nas primeiras linhas dos Tópicos é dito ser "dialético" em virtude do tipo de proposição que figura nas suas premissas. Enquanto a demonstração parte de proposições necessariamente verdadeiras, o argumento dialético tem endoxa como premissas (Top. I 1, 100a25-b23).

No âmbito restrito do debate dialético, o recurso aos endoxa pode ser explicado a partir da necessária anuência do respondedor para que uma proposição seja incluída no debate. Dada a reputação da opinião apresentada pelo questionador, o respondedor não pode recusá-la sem correr o risco de expor-se ao ridículo. ${ }^{14} \mathrm{Na}$ interpretação metodológica da dialética, por sua vez, é necessário explicar a importância dos endoxa conferindo-lhes um potentíssimo papel heurístico. Como se verá, há base textual para tomar os endoxa como desempenhando certa função de evidência a partir da qual se procede uma

${ }^{13}$ Antes de Barnes, não era raro encontrar quem traduzisse endoxa por "opiniões prováveis" (como faz Ross em sua tradução de 1908 da Metafisica : ver 995b24). Trata-se provavelmente da influência da tradução latina de Boécio, que recorria a "probabilis". O sentido do termo latino, no entanto, não corresponde a "provável", mas a "aprovado por" (Barnes : 1980, p. 500). Para uma avaliação extremamente favorável da tradução de endoxos por "reputável" (e da adoção de tal tradução na edição revista de The complete works of Aristotle, 1984), ver Burnyeat, 1986.

${ }^{14}$ Nesse sentido, ver Brunschwig (1967, p. xxxiv-xxxv). Ao explicar a importância dos endoxa para o debate dialético, Smith enfatiza o caráter relativo da noção de endoxa: o que é reputado, é assim para alguém. Desse modo, ao recorrer a um endoxon, o questionador apresentaria ao respondedor uma opinião cuja reputação é reconhecida por esse último, o que o inclina a aceitála (ver Smith : 1993, p. 343-349; 1997, p. xxiii-xxiv; 1999, p. 44-47). 
investigação. A esse respeito, no entanto, as dificuldades para o intérprete são diretamente proporcionais à envergadura da importância conferida aos endoxa.

A maior extensão dos Tópicos (livros II a VII) é dirigida sobretudo à exposição de topoi. Ainda que o sentido preciso com o qual o termo é empregado na obra seja discutível ${ }^{15}$, pode-se entender que, em linhas gerais, um topos constitui uma estratégia para a construção de um argumento cuja conclusão corresponde a uma proposição que se deseja estabelecer. No âmbito do debate dialético, o topos corresponde a uma ferramenta da qual o questionador se serve para buscar estabelecer a proposição contraditória à que fora assumida pelo respondedor.

Os Tópicos, assim, são uma obra em cujo núcleo está o debate dialético. A prática quase esportiva desse tipo de debate, no entanto, não esgota os seus propósitos. Em Tópicos I 2 (capítulo que aqui sigo de perto), Aristóteles lista as diversas utilidades do tratado, das quais apenas a primeira corresponde ao exercício intelectual (gumnasia) identificado com o tipo de debate cujas características foram esboçadas acima. ${ }^{16} \mathrm{~A}$ utilidade do tratado para esse fim, diz Aristóteles, é evidente por si mesma, uma vez que, dispondo de um método, seremos capazes de argumentar mais facilmente sobre qualquer tema que se apresente (101a28-30). Para além de sua utilidade com vistas ao exercício intelectual, diz Aristóteles, o tratado também é útil para as discussões compreendidas de maneira mais ampla (enteuxeis) ${ }^{17}$ e para as ciências de natureza filosófica (kata philosophian epistêmai). Aristóteles fundamenta o uso com vistas às enteuxeis dizendo que, tendo inventariado as opiniões da maioria das pessoas (o que está associado ao emprego dialético dos endoxa), podemos discutir com elas a partir das suas próprias crenças e não das de outrem. Com isso temos uma base para convertê-las ${ }^{18}$ naquilo que não nos parece ter sido bem dito. A referência à "maioria das pessoas" (hoi polloi) sugere que, ao falar das enteuxeis, Aristóteles tenha em mente a situação na qual o filósofo

\footnotetext{
${ }^{15}$ Um exame de diferentes interpretações propostas com relação à natureza precisa do topos pode ser encontrado no capítulo 2 de Slomkowski : 1997. Sobre o tema, ver ainda Brunschwig : 1967, p. xxxviii-xlv; Smith : 1997, p. xxiv-xxx e Pereira : 2000, p. 365-367.

${ }^{16}$ A esse respeito, ver Smith : 1997 ad loc. e Moraux : 1968, p. 288, n. 3.

${ }^{17}$ O sentido de enteuxis não é de todo claro. Ver Brunschwig : 1968, p. xii e Smith : 1997, p. 51.

${ }^{18} \mathrm{O}$ sentido preciso que Aristóteles confere ao verbo empregado, metabibazein, é discutível. Seu uso parece indicar uma conversão conduzida por argumentos (ver 161a33-36). A esse respeito, ver Dirlmeier : [1963] 1984, p. 184; Barnes : 1980, p. 507 e Smith : 1997, p. 52.
} 
discute com interlocutores do púbico não filosófico ${ }^{19}$. O sentido de enteuxeis, no entanto, não é de todo claro. ${ }^{20}$

De todo modo, a utilidade de maior relevância aqui evidentemente é aquela associada às ciências de natureza filosóficas. Ao que tudo indica, a qualificação "de natureza filosófica" ressalta que se encontra nas ciências em geral o vínculo intrínseco que Aristóteles compreende haver entre a philosophia e a busca desinteressada pela verdade (ver, por exemplo, Top. I 14, 105 b30 e Metaf. $\alpha 1$, 993b19-20; EN I 6, 1096a1417). ${ }^{21}$ Com efeito, a fundamentação dessa terceira utilidade conecta o exame diaporemático (tipicamente dialético) de posições contrárias entre si à busca pela verdade: "sendo capazes estabelecer aporias [diaporêsai] em relação a cada um dos lados contrários, seremos capazes de ver distintamente o verdadeiro e o falso" (101a34-36; ver também VIII 14, 163b9-16).

Assim concebida, a utilidade do tratado para o cientista e o filósofo é bastante evidente e decorre diretamente de seu conteúdo: o instrumental desenvolvido no tratado, afinal, tem por foco a construção de argumentos e a identificação de relações lógicas entre proposições (como as de contrariedade e contradição). No entanto, após mencionar a contribuição que o estabelecimento dialético de aporias dá à busca pela verdade, Aristóteles introduz um aspecto adicional da relação entre a dialética e as ciência:

[1] Além disso, este tratado é útil com vistas às coisas primeiras ${ }^{22}$ acerca de cada ciência. Com efeito, a partir dos princípios próprios de uma ciência dada é impossível dizer algo a seu respeito, uma vez que os princípios são primeiros em relação a todas as coisas. É, então, necessário

${ }^{19}$ Trata-se da função que Brunschwig denomina de "homilética", pela qual a dialética forneceria ao filósofo uma linguagem comum para as discussões com o não-filósofo (1967, p. xii). Em sentido semelhante, ver Smith : 1997, p. 51-52 e Alexandre : 28.1-22

${ }^{20}$ Uma interpretação diferente da que foi delineada pode ser encontrada, por exemplo, em Moreaux, que associa as enteuxeis ao aspecto peirástico da dialética (a respeito do qual se tratará adiante), o que não supõe um direcionamento particular ao público não-filosófico (1968, p. 290, n. 3).

${ }^{21}$ Brusnschwig (1967, p. 116-117) entende que o qualificativo kata tên philosophian demarca um uso propriamente filosófico da dialética em oposição à sua contribuição às ciências compreendidas à maneira dos Segundos Analíticos. Essa última aplicação especificamente científica da dialética passaria a ser discutida apenas a partir de 101a36. Essa leitura, no entanto, supõe uma distinção entre filosofia e ciência em termos que não são próprios do uso de Aristóteles (ver, por exemplo, Metaf. $\Gamma$ 2, 1004a2-9 e E 1, 1026a18-19). A esse respeito, ver Irwin : 1988, cap. 2, n. 35; Bolton : [1990] 1999, p. 64-65; Smith 1997, p. 52 e Berti : [1995] 2010, p. 313-314.

${ }^{22}$ Adotando-se em 101a37 a variante textual epistêmên archôn ao invés de epistêmên, tem-se "[este tratado] é útil com vistas aos primeiros principios acerca de cada ciência". 
escrutinar a seu respeito a partir dos endoxa relativos a cada assunto. ${ }^{23}$ Essa tarefa é ou exclusiva ou especialmente apropriada à dialética, pois, sendo examinadora, ela está desimpedida em relação aos princípios de todas as investigações. (101a36-b4)

Os intérpretes divergem quanto a haver nesse texto a introdução de uma subdivisão da utilidade de interesse filosófico-científico discutida em 101a34-36, ou a haver aí uma nova utilidade, independente da anterior. ${ }^{24} \mathrm{~A}$ utilidade relacionada aos princípios é introduzida em 131 a36 por um eti ("além disso"), o que normalmente marca a introdução de um novo ponto na discussão. Não é, no entanto, impossível que o novo ponto corresponda a uma subdivisão do anterior (como nota Alexandre: 29.18-23). Aristóteles, afinal, havia anunciado a exposição de três e não quatro utilidades para o tratado (101a26). Em qualquer das hipóteses, o texto [1] concede à dialética um papel especial com relação aos primeiros princípios. A questão a ser enfrentada pelo intérprete, evidentemente, consiste em determinar precisamente qual seja esse papel. A última frase, cuja tradução será discutida adiante, é usualmente traduzida da seguinte maneira: "[a dialética] tem um caminho em direção aos princípios de todas as investigações”. Com base nessa tradução usual, muitos intérpretes entendem que [1] atribui à dialética o papel de conduzir ou dar acesso aos primeiros princípios, ou seja, aos pontos de partida com base nos quais são construídas as demonstrações científicas.

Não há como exagerar a importância que se atribui à dialética concedendo-lhe tal papel. Com efeito, as ciências demonstrativas dependem da apreensão de primeiros princípios, tarefa que não pode ser desempenhada por elas próprias (ver, por exemplo, Segundos Analíticos. I 2, 72a25 ss. e I 9, 76 a16 ss.). Assim sendo, o texto [1] é tomado como fornecendo forte apoio para as leituras que procuram na dialética a fonte de um método de importância capital para a filosofia de Aristóteles. Além disso, seja qual for a natureza do papel que [1] concede à dialética em relação aos princípios, é certo que ele dependa de endoxa (101b1). Desse modo, ainda que em grande parte dos Tópicos a

\footnotetext{
${ }^{23} \mathrm{Ou}$ "acerca de cada princípio", dependendo de como se compreenda a referência de peri hekasta em $101 \mathrm{~b} 1$.

${ }^{24}$ Brunschwig (1967, p. xii; 116-117) defende a segunda alternativa em parte a partir de sua posição a respeito da restrição do escopo da utilidade discutida em 101a34-36 ao conhecimento filosófico compreendido em oposição à ciência (ver nota 21). Em sua perspectiva, o eti de 131a36 abriria caminho à apresentação de uma quarta utilidade - a única propriamente relacionada às ciências. Uma defesa da segunda alternativa também pode ser encontrada em Zingano : 2004, p. 35-36. Para defesas da primeira alternativa ver Alexandre 29.18-30.12; Irwin : 1988, cap. 2, n. 35; Pereira : 2000, p. 370ss (ver ainda tradução fornecida à p. 356); 2004, p. 153-155 e Berti : [1995] 2010, p. 313-314.
} 
importância dos endoxa esteja associada à natureza do debate dialético, o texto [1] fornece algum suporte para a tese segundo a qual as opiniões reputáveis estejam na base de um procedimento metodológico proeminente.

Nem todas as interpretações que buscam na dialética a origem fundamental do método de Aristóteles atribuem importância decisiva ao texto [1]. De modo geral, no debate recente tem maior relevância a passagem metodológica de EN VII 1, 1145b2-7 (sobretudo no que diz respeito ao método da ética). A despeito disso, não há como ignorar o interesse de [1] para o tema. Com efeito, essa passagem é a primeira a ser referida por Burnet na porção de seu texto mais diretamente ocupada com a natureza da dialética (ver 1900, p. xl, incluindo nota 1) e ele a lê nos termos que foram delineados acima. Dela, Burnet conclui que "acima de tudo, [a dialética] presta-se à descoberta dos primeiros princípios ou pontos de partida das diferentes ciências" (ibid. grifo meu). ${ }^{25}$

Desse modo, antes de passar ao exame da passagem metodológica de EN VII 1, cabe discutir o alcance e a natureza do procedimento com relação aos princípios que o texto [1] atribui à dialética.

\section{Um caminho aos princípios?}

Uma análise exaustiva das interpretações que encontram em [1] a atribuição à dialética da capacidade de conduzir aos princípios deve examinar em detalhes os diferentes modos pelos quais tais interpretações compreendem o que seja "dar acesso aos primeiros princípios". ${ }^{26}$ No entanto, em qualquer sentido que se compreenda o papel de

\footnotetext{
${ }^{25}$ No que diz respeito à ética, a concepção da dialética como um método que conduz aos primeiros princípios associou-se à tese segundo a qual a ética, ao contrário das ciências demonstrativas, procederia em direção aos primeiros princípios e não a partir deles. Essa última tese parte de uma leitura de EN I 4, 1095a30-b8. Exemplos de interpretações que tomam a passagem como indício de que a dialética corresponde ao bom método em ética podem ser vistos em Burnet : 1900, p. 16 e Ross, : [1923] 1995, p. 199. Uma crítica a tais leituras de EN I 4, 1095a30-b8 é feita por Hardie : 1980, pp. 34-37.

${ }^{26}$ Burnet (1990, p. xli-xlii), por exemplo, entende que [1] atribui à dialética a capacidade de descobrir os princípios, mas não de prová-los. Nessa perspectiva, tendo encontrado um primeiro princípio pela via da dialética, não seria necessário (nem possível) fornecer qualquer prova de sua verdade, que seria imediatamente apreendida. De modo semelhante, Pereira, que entende caber à dialética "de modo eminente, a competência para a aquisição dos princípios da ciência" (2000, p. 370 ), sustenta que "o conhecimento dos princípios emerge da argumentação dialética sem ser engendrado por ela, os princípios conhecem-se graças a ela, ainda que não por ela" (2000, p. 372; ver também 2004, p. 151-152).
} 
conduzir aos princípios, a atribuição dessa tarefa à dialética enfrenta dificuldades consideráveis.

Em primeiro lugar, parece claro que tal tarefa não pode corresponder sem mais ao estabelecimento dos primeiros princípios. Aristóteles, afinal, afirma que a crença (pistis) nos princípios dá-se em virtude deles próprios e não de algo distinto, sendo inadequado investigar o seu porquê (Top. I 1, 100b18-21). Isso veda a atribuição à dialética da tarefa de estabelecer princípios e coloca sob suspeição as pretensões de encontrar em [1] a atribuição à dialética de um papel forte com relação à apreensão dos princípios. ${ }^{27}$

Além disso, concessão à dialética de um papel decisivo com respeito aos princípios contrasta fortemente com os limites que Aristóteles frequentemente afirma existirem para tal arte. O papel de buscar a verdade, afirma Aristóteles, cabe à filosofia e não à dialética. (Top. I 14, 105b30, ver também Metaf. Г2, 1004b25-26 e B1, 995b22-25). ${ }^{28}$ Diante disso, é algo surpreendente que Aristóteles conceda justamente à dialética a tarefa de dar acesso os princípios das ciências, cujas demonstrações devem começar e terminar com proposições asseguradamente verdadeiras.

Adicionalmente, deve-se notar que as interpretações que seguem por tal caminho precisam conceder aos endoxa um imenso valor epistemológico. Nisso há uma considerável dificuldade. Afinal, a despeito da boa reputação da qual possam gozar as opiniões reputáveis, elas não deixam de ser tomadas como opiniões e, como tal, podem ser falsas (ver Refutações Sofísticas 181a15-17; Top. $162 \mathrm{~b} 28$ ss.). Os primeiros princípios, por sua vez, devem ser verdadeiros (ver, por exemplo, Top. I 1, 100a27-30; Seg. An. I 2, 71b19-21), o que torna problemático estabelecê-los a partir de meras opiniões.

Finalmente, a atribuição de um papel forte à dialética com relação aos princípios cria dificuldades quanto às relações entre Top. I 2 e Seg. An. II 19, onde a apreensão dos princípios é reservada ao nous. ${ }^{29}$

${ }^{27}$ Essa dificuldade motiva a introdução por Burnet da distinção entre descoberta e prova, bem como a limitação que Pereira opera sobre o papel da dialética na apreensão dos princípios (ver nota anterior).

${ }^{28}$ As limitações da dialética a esse respeito são exploradas de modo muito enfático por Hussein: "[a dialética] não tem a habilidade de atingir a verdade ou o conhecimento" (1999, p. 3).

${ }^{29}$ Pereira pretende conjugar os papeis da dialética e do nous, de modo que à dialética caberia revelar o princípio, ao passo que o reconhecimento de sua verdade dar-se-ia imediatamente pelo nous: "a partir do método dialético-indutivo e graças a ele, pode operar-se um salto em que outro modo surge - isto é: a inteligência [sc. nous] - de mostrar-se a verdade dos princípios" (2000, p. 389-390). Uma vez que a dialética tenha realizado o seu papel com relação aos princípios, ela 
Seja qual for o papel atribuído em [1] à dialética em relação aos princípios, é de amplo reconhecimento que Aristóteles diz muito pouco para esclarecê-lo. Os detalhes do modo como a dialética funciona a esse respeito ficam inteiramente a cargo do intérprete. ${ }^{30}$ Em princípio, nisso há uma dificuldade para toda e qualquer leitura de [1]. No entanto, a dimensão das dificuldades cresce na medida da ambição disposta na dialética com relação aos princípios.

Tendo isso em vista, alguns intérpretes propuseram leituras moderadas para [1], evitando encontrar ali a atribuição à dialética o papel de dar acesso aos princípios. ${ }^{31}$ Entre os autores recentes, Robin Smith é o mais influente defensor de uma tal leitura para [1]. ${ }^{32}$ Como nota Smith (1993, p. 352; 1997, p. 52-55; 1999, p. 51), o papel da dialética em relação aos princípios é caracterizado em [1] por contraste às limitações das ciências a esse respeito. Dado que as demonstrações científicas partem dos princípios, não é possível às ciências demonstrativas dizer algo (101a39) a seu respeito. Diante disso, cabe à dialética discutir ${ }^{33}$ acerca dos princípios. Ora, como observa o autor, a alternativa a ser incapaz de dizer algo sobre os princípios é poder dizer algo a seu respeito, o que pode não corresponder propriamente a conduzir a eles.

Com efeito, defensores da leitura moderada de [1] costumam sustentar que o papel da dialética com respeito aos princípios é de natureza fundamentalmente negativa. A

cederia lugar a uma "intuição plena, absoluta e infalível [sc. dos princípios] que não se acompanha de discurso" (ibid.). De maneira semelhante, tendo limitado o papel da dialética à descoberta (e não à prova) dos princípios, Burnet recorre ao suposto caráter intuicionista da filosofia aristotélica para assegurar a apreensão de sua verdade (1900, p. xli-xlii). A ideia de uma apreensão intuitiva da verdade dos princípios, no entanto, é problemática por razões cujo exame excederia o escopo deste trabalho (a esse respeito, ver, por exemplo, Barnes : [1975] 1993, p. 267 ss.; Zingano : 2004, p. 28). Além disso, como tem sido apontado por vários intérpretes recentes, apreender um princípio não envolve apenas tomá-lo como verdadeiro, mas identificar seu papel de princípio em relação a outras proposições (McKirahan : 1992, p. 243-244; Zuppolini : 2017, p. 41-46; para uma discussão do ponto, ver também Bronstein : 2016, p. 62-63). Nesse caso, a ideia de descoberta esvazia-se de sentido quando dela se exclui a apreensão do papel que o princípio tem em relação às proposições das quais ele é princípio. Trata-se, novamente, de uma tarefa cuja execução a partir de endoxa é de difícil compreensão.

${ }^{30}$ Uma proposta engenhosa que combina a adoção de premissas endoxais com raciocínios indutivos e que é acompanhada da elaboração de exemplos concretos pode ser encontrada em Alexandre 29.18 ss.

${ }^{31}$ Para leituras tradicionais que seguem nessa direção, ver, por exemplo, Grote (1872, v. I, p. 391 394) e Hamelin (1920, p. 230-235).

${ }^{32}$ Ver Smith : 1993, p. 351-354; 1997, p. xvi-xx, 52-55; 1999, p. 50-53.

${ }^{33}$ Termo que traduz dielthein em $101 \mathrm{~b} 2$ e para o qual adotei a tradução "escrutinar". Sobre seu uso em Aristóteles para marcar o início e o encerramento do tratamento de um tema, ver Smith (1997, p. 52; 1999, p. 51). 
contribuição da dialética para a apreensão dos princípios estaria associada à sua capacidade de identificar inconsistências e contradições, de modo que seu papel seria, mais do que qualquer coisa, o de auxiliar na identificação de hipóteses problemáticas. Trata-se da função dita "peirástica" (ou "testadora"), que é frequentemente associada à dialética por Aristóteles (por exemplo: Ref. Sof. 11, 171b4-6; 172a21; Metaf. Г2, 1004b25-26). Nas palavras de Moraux, "enquanto peirastikê, a dialética não pretende demonstrar uma verdade, mas trazer à luz a ignorância de alguém que pretende saber" $(1968$, p. 288, n. 3$) \cdot{ }^{34}$

A esse respeito, Smith chama a atenção sobre o uso pouco comum do adjetivo exetastikê em 101b3, que traduzi por "examinadora" e para o qual Smith propõe as traduções "crítica" ou "testadora". Seu uso indica que, ao tratar do papel da dialética com respeito aos princípios, Aristóteles tem em mente seu papel negativo, uma vez que o termo exetastikos remete à atividade socrática de submeter as crenças de seus interlocutores a exame (exetazein) com o objetivo de expor sua ignorância por meio da identificação de inconsistências. A atribuição desse papel predominantemente negativo à dialética é ainda reforçada pela explícita conexão com a figura de Sócrates (Ref. Sof. 34, 183b-6-8) e pela indicação da refutação como característica intrínseca da dialética (Ref. Sof. 2, 165b3-4). ${ }^{35}$

Os modos mais diretos de compreender essa assistência pela via negativa dão-se pela eliminação de hipóteses impróprias a partir do reconhecimento de seus problemas ${ }^{36}$ e à maneira de uma caução para as boas alternativas, que se mostrariam resistentes às objeções após o exame dialético. ${ }^{37} \mathrm{~A}$ atividade de revelar inconsistências pode, também, ter um resultado sobre a disposição do cientista que, identificando os problemas das crenças aceitas (os endoxa mencionados em [1]), torna-se consciente do estado de ignorância sobre o tema. Trata-se, como Aristóteles enfaticamente afirma (Metaf. A1-2 e Gen. Corr. I 2, 316a5-10), do primeiro passo para a investigação científica. Smith, que

${ }^{34}$ Ver ainda Zingano, para quem a dialética pode "sempre dizer algo a respeito dos princípios via negationis (2004, p. 41).

${ }^{35}$ Em direção semelhante segue Zingano (2004; em especial, p. 40-41).

36 "A dialética, acerca de cada princípio, ensina sobretudo onde não se deve procurar" (Hamelin : 1920, p. 235).

37 “[Aristóteles] não quer dizer que esses principia podem ser provados pela Dialética, pois a Dialética não prova coisa alguma, mas que ela é necessária como um teste ou processo escrutinador para nos assegurar de que todas as objeções capazes de serem oferecidas contra eles podem ser confrontados com respostas suficientes" (Grote : 1872, v. 1, p. 393). 
ressalta esse aspecto da peirástica, nota ainda que, ao identificar inconsistências, a dialética também ajuda a estabelecer a agenda para a investigação (1993, p. 351-354; 1997, p. xvi-xx, 52-55; 1999, p. 50-53). ${ }^{38}$

Uma fonte de resistência às interpretações moderadas de [1] pode estar em sua frase final (101b3-4), que, nas traduções usuais, informa que a dialética "sendo examinadora, [...] tem um caminho [hodon echei] em direção aos princípios de todas as investigações". Essa frase parece atribuir à dialética uma via para se chegar aos princípios, o que expressaria uma tese mais forte do que aquela adotada pelas leituras moderadas. Para contornar a dificuldade, Smith propôs uma construção alternativa para a sintaxe do trecho (1993, p. 353-354; 1997, p. 54-55). Usualmente, toma-se pros tas hapasôn tôn methodôn archas ("em direção aos princípios de todas as investigações") como complemento de hodon echei ("tem um caminho", nas traduções usuais), do que resulta a frase recém reproduzida. Smith, por sua vez, vincula "princípio de todas as investigações" a "examinadora" (exetastikê). Desse modo, sua tradução para o trecho resulta ser "uma vez que a sua habilidade [a saber, da dialética] aplica-se aos pontos de partida de todos os estudos, ela tem um modo de proceder".

A leitura de Smith, no entanto, não é natural. É questionável que caiba vincular pros tas hapasôn tôn methodôn archas a exetastikê e não a hodon echei. ${ }^{39}$ Smith (1997, p. 179) busca apoio em Historia Animalium IX 40, 625a13, onde se lê hotan (...) mê echôsin hodon hê(i) prosporeusontai ("quando quer que não tenham passagem pela qual avancem"). Seu interesse na passagem se dá, provavelmente, por se tratar de caso em que hodos ocorre sem complemento. ${ }^{40} \mathrm{O}$ suporte que a leitura de Smith pode encontrar em tal evidência, contudo, é muito limitado.

Não é, no entanto, necessário ler 101b3-4 à maneira de Smith para adotar a leitura moderada de [1]. Marco Zingano (2004, p. 34-35) sugere que a expressão hodon echei tenha valor idiomático, remetendo a Metaf. I4, 1055a6-7, onde se lê que as diferenças quanto ao gênero ouk echei hodon eis allêla ("não têm um caminho umas em direção às outras", de acordo com a tradução usual). O ponto seria que as diferenças "não têm nada

${ }^{38}$ Uma interpretação diversa e bastante peculiar do uso peirástico da dialética pode ser encontrada em Bolton [1990] 1999.

${ }^{39}$ Slomkowski $(1999$, p. 24$)$ recusa a leitura de acordo com a qual exetastikê tomaria pros tas hapasôn etc. como seu complemento. De acordo com sua objeção, se estivesse correta a leitura de Smith, o complemento de exetastikê estaria expresso por meio do genitivo e não da preposição pros.

${ }^{40}$ Para a compreensão de Smith da expressão hodon echei, ver ainda 1993, p. 354. 
a ver umas com as outras, ou, em outros termos, não se comunicam" (2004, p. 35, grifo do autor). Como nota Zingano, assim compreendida, a expressão diz menos do que sugere a tradução usual de hodon echei por "ter um caminho" que, em português, seria correspondente a "ter a chave para". ${ }^{41}$ Em [1], a expressão hodon echei concederia à dialética a mesma prerrogativa com relação aos princípios que lhe fora atribuída por contraste às restrições das ciências: ao passo que essas não podem dizer algo acerca dos princípios, aquela pode fazê-lo. Entendida desse modo, a expressão hodon echei apenas indicaria que a dialética, ao contrário das ciências, pode tratar dos princípios. Justamente para capturar essa relação fraca que a dialética teria com os princípios, traduzi pros tas hapasôn tôn methodôn archas hodon echei em [1] por "ela [a dialética] está desimpedida [hodon echei] em relação aos princípios de todas as investigações”.

Assim, considerando-se a quantidade de passagens nas quais a dialética é contrastada com a apreensão da verdade e o fato que os endoxa constituem uma base muito incerta para o estabelecimento de princípios indemonstráveis, torna-se razoável adotar a leitura moderada de [1]. A dialética permite tratar dos princípios, que jamais são objeto das próprias ciências, a partir do teste das opiniões reputáveis a seu respeito. Ela, desse modo, auxilia na apreensão dos princípios por seu aspecto peirástico, uma vez que permite identificar contradições e inconsistências em tais opiniões, eliminando as hipóteses problemáticas e auxiliando no estabelecimento de uma agenda para o cientista.

\section{A leitura tradicional da passagem metodológica de EN VII 1}

Não é exagero dizer que, ao menos desde Owen, não há qualquer texto cuja importância para a discussão do método de Aristóteles seja maior do que a da célebre passagem metodológica de EN VII 1, cuja tradução forneço a seguir, grifando os termos que serão objeto de discussão adiante:

[2] Deve-se, como em outros casos, (A) tendo estabelecido o que é manifesto [ta phainomena] e (B) tendo primeiramente examinado as aporias [diaporêsantas], (C) provar [deiknunai] desse modo sobretudo todas as opiniões reputáveis [endoxa] sobre essas afecções e, se não isso, provar a maioria e as principais [kuriotata] dentre elas. Com efeito, (D) quando se solucionam as

\footnotetext{
${ }^{41}$ Pereira, cuja interpretação de [1] corresponde ao alvo das considerações de Zingano, recusa a equiparação entre "ter um caminho" e "ter a chave para". Segundo o autor, aplicada a [1], a equiparação sugeriria que a dialética oferece uma via segura à aquisição dos princípios. A despeito de adotar uma interpretação forte quanto à relação entre a dialética e os princípios, Pereira enfatiza que a dialética está longe de ser infalível na realização de sua tarefa (2004, p. 150-153).
} 
dificuldades e permanecem as opiniões reputáveis [kataleipêtai ta endoxa], (E) o ponto terá sido suficientemente estabelecido. (EN VII 1, 1145b2-7)

Essa passagem é não raro associada ao texto [1]. ${ }^{42} \mathrm{Nela}$, no entanto, não há qualquer menção a princípios, nem tampouco o contexto no qual está inserida diz respeito ao estabelecimento de princípios. ${ }^{43}$ Seu exame, portanto, deve ser feito independentemente de [1].

A despeito disso, [2] traz à mente os Tópicos, uma vez que propõe um procedimento que se aplica sobre endoxa (C), tomando apoio no estabelecimento de aporias (B). Essas duas características fazem ressoar o ponto de partida designado pelos Tópicos aos argumentos dialéticos e a tarefa própria do questionador, que deve buscar estabelecer uma contradição ou, na falta disso, consequências paradoxais a partir da tese assumida pelo respondedor. Caberá verificar se a isso corresponde uma relação estreita entre o procedimento descrito em [2] e a dialética ou se os pontos de contato a esse respeito são superficiais.

O texto [2] propõe um procedimento metodológico cuja aplicação claramente não está restrita ao contexto imediato da passagem, como se vê em sua abertura, onde se afirma que os passos a serem apresentados dão-se "como em outros casos". A mera menção aos demais casos é frequentemente tomada como indício de que o procedimento é de ampla aplicação em Aristóteles. Por si mesma, no entanto, tal menção não delimita qualquer âmbito de aplicação e, a meu ver, ela é frequentemente explorada com exagero pelos intérpretes. ${ }^{44}$ Como nota Cooper (2009, p. 27), ainda que a expressão contenha um artigo definido ("como nos outros casos"), ela não deixa claro quais são casos que

${ }^{42}$ Para leituras influentes que associam [2] a [1], ver Owen (1967, p. 87) e Berti ([1995] 2010, p. 317).

${ }^{43}$ Ver Cooper (2009, p. 19-20). Para uma interpretação que relaciona [2] à busca de princípios, ver Irwin (1999, p. 326-327).

${ }^{44}$ Alguns intérpretes sustentam que a menção deva ser compreendida como dizendo respeito a todos os outros casos, de modo que a passagem de EN VII 1 corresponderia à exposição da proposta metodológica de Aristóteles para todos os contextos e não apenas para a ética (ver Nussbaum : 1986, p. 240). Ross (1925) chegou a traduzir hôsper epi tôn allôn por "assim como em todos os casos", ainda que o texto grego não comporte nenhum termo que corresponda a "todos". A tradução de Ross para a expressão foi mantida na versão de 2009, revista por Brown. Interpretações consideravelmente mais restritivas quanto ao escopo dos "outros casos" mencionados no início da passagem podem ser encontradas, entre outras, nas seguintes obras: Bostock : 2000, p. 234; Pakaluk : 2005, p. 235-238; Cooper : 2009, p. 27; Frede : 2012, p. 208 n. 54. 
Aristóteles tem em mente (e é, portanto, prudente incorporar à tradução a indeterminação do âmbito de aplicação do método: "como em outros casos").

O núcleo de [2] está contido em seu trecho $\mathrm{C}$, pelo qual fica claro que o procedimento proposto se aplica sobre endoxa. Trata-se não de um conjunto qualquer de endoxa, mas de um conjunto que, idealmente, compreende todas as opiniões reputáveis sobre o assunto investigado (panta ta endoxa: 1145b4-5). O mesmo trecho deixa claro que no foco do procedimento está o estabelecimento de um resultado que abarca a maior porção possível das opiniões coletadas: se não for possível abarcar todas no resultado estabelecido, deve-se fazê-lo ao menos com relação à maioria ou às principais. No texto de Aristóteles, o estabelecimento do resultado é referido pelo verbo deiknunai (1145b4), que usualmente é traduzido como "provar". Na tradução de [2] exposta acima, mantive provisoriamente essa tradução usual para o termo. Entendo, no entanto, que o sentido do verbo no contexto precisa ser examinado e, na discussão, empregarei a expressão indeterminada "estabelecer um resultado".

Pode-se, assim, concluir com segurança que o procedimento proposto por [2] tem ao menos as seguintes características:

1) Formação de um conjunto maximal $\Delta_{i}$ de opiniões reputadas sobre o assunto sob investigação; 2) Busca de um resultado abarcando, se não todas as opiniões contidas em $\Delta_{\mathrm{i}}$, ao menos a maioria e as principais.

O texto também deixa claro em B que:

3) O estabelecimento do resultado envolve o exame de aporias com respeito às opiniões contidas em $\Delta_{\mathrm{i}}$.

Fica ainda claro a partir de D que:

4) O procedimento se encerra com a permanência em maior grau possível das opiniões coletadas.

A despeito do que esteja estabelecido em 1-4, resta ainda muito a se determinar. Em primeiro lugar, deve-se discutir o sentido preciso do estabelecimento do resultado que se obtém com respeito aos endoxa contidos em $\Delta_{\mathrm{i}}$. Além disso, será necessário discutir a natureza das aporias cujo exame caracteriza o procedimento, bem como a permanência dos endoxa que caracteriza a obtenção do resultado final.

A respeito do último ponto, é fundamental para a discussão a seguir notar que a permanência dos endoxa no resultado final é usualmente interpretada como correspondendo à formação de um conjunto $\Delta_{\mathrm{f}}$ de afirmações cuja verdade é reconhecida pelo investigador. 
É comum que os phainomena em A sejam tomados como correspondendo aos endoxa de $\mathrm{C}$ e a prova mencionada em $\mathrm{E}$ como dizendo respeito ao mesmo resultado referido em C. ${ }^{45}$ Quando os phainomena de A são identificados com os endoxa, o passo inicial do procedimento corresponde integralmente à formação do conjunto $\Delta_{\mathrm{i}}$. Além disso, se não há distinção entre a resultado referido em $\mathrm{E}$ e aquele mencionado em $\mathrm{C}$ e se a permanência mencionada em D é compreendida como "tomar como verdadeiro", então o resultado do procedimento corresponde a um conjunto $\Delta_{\mathrm{f}}$ de opiniões tomadas como verdadeiras que contém, se não todos os itens de $\Delta_{\mathrm{i}}$, ao menos a maior parte e os principais.

Desse modo, uma leitura bastante natural de [2] encontra lá um procedimento que se estrutura inteiramente em torno a endoxa, partindo de formação de um conjunto de tais opiniões sobre o tema da investigação e tendo por objetivo a composição de um segundo conjunto derivado do primeiro e composto apenas por opiniões que são tomadas como verdadeiras pelo investigador.

Nessa leitura, o procedimento descrito em [2] pode bem ser tomado como sendo de natureza "dialética". O papel central que os endoxa têm no procedimento estabelece, já, uma conexão de [2] com a arte dialética dos Tópicos. Esse vínculo torna-se mais estreito quando o exame de aporias mencionado em B é entendido como processo de identificar e explorar incompatibilidades entre as opiniões reunidas em $\Delta_{\mathrm{i}}$. Nos Tópicos, o estado de perplexidade mental que corresponde à aporia surge da igualdade de raciocínios contrários (VI 6, 145b1-2). Nesse contexto, o termo está associado à prática de raciocinar em direções opostas com respeito a uma mesma questão, ou seja, de explorar as linhas de raciocínio relacionadas a respostas conflitantes para o mesmo problema (VI 6, 145b1720). Trata-se, fundamentalmente, do procedimento que é comumente associado ao exame de aporias no trecho B de [2]. ${ }^{46} \mathrm{O}$ exame de "aporias", então, lembra o papel do questionador no debate dialético e o procedimento como um todo parece identificar-se com a terceira utilidade discernida Top. I 2. Trata-se do benefício que as ciências de natureza filosófica obtêm da capacidade de armar aporias (diaporêsai) em relação a cada

\footnotetext{
${ }^{45}$ Uma das poucas vozes dissonantes é Berti (ver [1995] 2010, p. 322-324), que não identifica os phainomena com os endoxa nem o resultado mencionado em E com aquele que é referido em $\mathrm{C}$. A meu ver, no entanto, sua leitura de [2] demanda que o intérprete adicione muito ao texto de Aristóteles.

${ }^{46}$ Nesse sentido, ver Irwin: "A discussão dessas crenças comuns mostra que elas dão lugar a dificuldades, aporiai, quando encontramos argumentos aparentemente convincentes a partir de crenças comuns para conclusões inconsistentes." (1999, p. 326).
} 
um dos lados de uma questão, atividade que ajudaria a discernir o verdadeiro do falso (101a34-36)

Nessa leitura que, por sua influência, chamarei de "leitura tradicional" de [2] (ou “leitura T”), o esforço para solucionar as incompatibilidades entre as opiniões contidas em $\Delta_{\mathrm{i}}$ conduziria à formação de $\Delta_{\mathrm{f}}$. Caberia ao investigador tentar resolver os conflitos preservando tanto quanto possível as opiniões de $\Delta_{\mathrm{i}}$.

Diversas interpretações do método da ética em Aristóteles filiam-se em maior ou menor grau a essa compreensão de [2]. Ainda que grande parte dos intérpretes não baseie sua compreensão do método integralmente na leitura $T$, ela exerce notável influência sobre muitas propostas interpretativas.

De T decorrem características usualmente atribuídas ao método de Aristóteles. Em particular, a leitura T sugere que o método de Aristóteles é conservador, uma vez que está centrado em opiniões reputáveis, partindo de sua coleta em $\Delta_{\mathrm{i}}$ e buscando mantê-las em $\Delta_{\mathrm{f}}$. Compreendido à maneira de $\mathrm{T}$, o método não prevê a adoção de teses externas ao conjunto inicial de endoxa e seu objetivo é fundamentalmente a ordenação coerente das teses já contidas em $\Delta_{\mathrm{i}}$. Assim, já Stewart tomava o objetivo da ética aristotélica como consistindo na "formação [itálico do autor] das opiniões comuns em um sistema" (1892, v. 2, p. 121$)^{47}$ e ainda atualmente não é raro que se descrevam os propósitos da ética de Aristóteles nos termos do conservadorismo que emerge da leitura T de [2]. ${ }^{48}$

Em seu conservadorismo, o esboço metodológico que surge de T tem uma marcada generosidade quanto às opiniões a serem consideradas. Com efeito, têm lugar reservado em $\Delta_{\mathrm{i}}$ todas as opiniões reputáveis sobre o tema (panta ta endoxa). ${ }^{49}$ Além disso, o

\footnotetext{
${ }^{47}$ A passagem, tomada em seu contexto, faz ressoar claramente a leitura $\mathrm{T}$ de [2]: "Consistindo a ciência moral como que na formação das opiniões comuns em um sistema, o moralista deve começar por enunciar tais opiniões. Ele deve, em seguida, arranjá-las de modo a expor claramente as inconsistências que elas apresentam umas em relação às outras. Ele está, então, em posição de ver mais ou menos claramente por que elas se apresentam como inconsistentes e sugere-se por si mesmo a ele reconciliar as inconsistências pelo estabelecimento de distinções necessárias [...]" (1892, v. 2, p. 121).

${ }^{48}$ Veja-se, por exemplo: “A tarefa de Aristóteles não é promover o entendimento a um novo nível, mas destilar a verdade implícita em opiniões preservadas" (Haskins : 2004, p. 6). Com relação ao conservadorismo do método compreendido à maneira de $\mathrm{T}$, ver ainda Barnes $(1980$, p. 496-497 e 510), que procura enfatizar que a atribuição de tal característica ao método não o restringe ao senso comum.

${ }^{49}$ Sobre a generosidade do método compreendido segundo a hipótese tradicional, ver Zingano (2007, p. 454, ss.). De acordo com Zingano, a generosidade do método explica a atitude acolhedora de Aristóteles para com uma tese que, de início, seria discrepante em relação à posição aristotélica, a saber, a tese de Sócrates com relação à incontinência (discussão que ocorre em EN
} 
procedimento é caracterizado pelo esforço de, tanto quanto possível, manter em $\Delta_{\mathrm{f}}$ as opiniões inicialmente coletadas. A essa última característica denominarei preservacionismo.

Esses três traços que a leitura $\mathrm{T}$ de [2] indica serem características do método da ética dispõem imensa confiança nos endoxa. De fato, o esboço metodológico composto a partir de $\mathrm{T}$ impõe que a investigação parta de todos os endoxa sobre seu objeto (generosidade) e apenas deles (conservadorismo). Se o procedimento delineado em [2] tem o valor de uma prova que se caracteriza pela identificação de verdades no seio dos endoxa coligidos (como na interpretação $\mathrm{T}$ da ideia de permanência em $\mathrm{E}$ ), então as opiniões reputáveis devem ter grande valor heurístico.

Com efeito, Aristóteles frequentemente encontra alguma verdade em endoxa (ver, por exemplo, Política, 1281a41-42), fato usualmente associado à tese que ficou conhecida como "otimismo aristotélico". Trata-se da tese, frequentemente atribuída a Aristóteles, segundo a qual o aparato cognitivo humano é naturalmente inclinado à apreensão da verdade. Essa tese encontra amparo textual em diversas passagens bem conhecidas ${ }^{50}$ e é inegável que Aristóteles tenha alguma confiança no valor dos endoxa como evidências úteis à busca da verdade (especialmente em sua filosofia prática). ${ }^{51}$ No entanto, a formulação precisa, bem como o alcance do otimismo aristotélico são discutíveis. ${ }^{52}$

Como observei já em mais de uma ocasião neste trabalho, as dificuldades do intérprete a esse respeito aumentam à razão de quanto se espere que seja possível estabelecer a partir dos endoxa. Uma dificuldade central para as interpretações tradicionais diz respeito justamente à formação de um conjunto de proposições

VII e é precedida pela passagem metodológica de 1145b2-7). Como ficará claro a seguir, procuro explicar de outro modo o papel da tese socrática na discussão da incontinência.

${ }^{50}$ Veja-se, por exemplo: "os homens inclinam-se naturalmente de modo suficiente ao verdadeiro e na maior parte dos casos encontram a verdade" (Ret. I 1, 1355a15-17). Outras passagens usualmente citadas como evidência para a atribuição da tese otimista epistemológica a Aristóteles incluem as seguintes: Metaf. a1, 993a30-b7; EN I 8, 1098b27-29 e EE I 6, 1216b30-32.

${ }^{51}$ A esse respeito, considero que excessivo o ataque de Smith ao valor epistemológico dos endoxa (por exemplo, 1999, p. 47ss.). Com efeito, são inúmeras as passagens nas quais Aristóteles busca alguma forma de apoio em opiniões que inequivocamente se contam entre os endoxa, como opiniões muito difundidas, ditos, provérbios e as posições de filósofos e outros sábios ilustres. Para fornecer apenas alguns (dentre muitos) exemplos, remeto às seguintes passagens: EN I 5; EN I 8, 1098b22-31; EN VI 11, 1143b10-14; EN X 8, 1168 b6 ss.

${ }^{52}$ Exames do tema podem ser encontrados nas seguintes obras: Burnyeat : 1986; Denyer :1991, cap. 10; Cleary : 1994; Johansen : 1999; Haskins : 2004. Um exame crítico da compreensão tradicional do otimismo aristotélico pode ser encontrado em Bolton : [1990] 1999, p. 92-94. 
supostamente verdadeiras $\left(\Delta_{\mathrm{f}}\right)$ a partir de um conjunto de endoxa $\left(\Delta_{\mathrm{i}}\right)$. Não surpreende que o conjunto de proposições que o investigador almeja estabelecer seja composto exclusivamente de proposições verdadeiras ${ }^{53}$. A dificuldade, no entanto, diz respeito à pretensão de estabelecer tal conjunto partindo de endoxa. Como notei acima, ainda que gozem de boa reputação, os endoxa não deixam de ser tomados como opiniões que podem ser falsas - algo que nenhuma interpretação do otimismo aristotélico poderia negar. Essa dificuldade é frequentemente apontada pelos intérpretes, que reagem a ela de diferentes maneiras. Trata-se de uma dificuldade que não é pequena e obriga os defensores de interpretações afiliadas à leitura $\mathrm{T}$ de [2] a formular hipóteses que excedem bastante $\mathrm{o}$ que se encontra no texto de Aristóteles.

$\mathrm{Na}$ análise das limitações que encontro na leitura T e que será desenvolvida a seguir, deixarei de lado essa dificuldade bem conhecida e passarei a concentrar-me em outros aspectos do procedimento. Estarei ocupado com as questões que surgem a partir do modo como a leitura $\mathrm{T}$ compreende o suposto processo de formação do conjunto $\Delta_{\mathrm{f}}$ a partir de $\Delta_{\mathrm{i}}$. Meu interesse será determinar se de fato cabe sustentar que Aristóteles tem como objetivo central manter tanto quanto possível os endoxa que formam o ponto de partida da investigação. Com isso, pretendo verificar até que ponto se pode tomar a leitura $\mathrm{T}$ do texto [2] como base para a concepção de um método de amplo escopo e identificar o tipo de demanda que ela cria para o intérprete que pretende tomá-la como tal. Espero mostrar que a proposta metodológica extraída da leitura $\mathrm{T}$ harmoniza-se apenas limitadamente com a prática de Aristóteles e que as concepções do método que nela se baseiam exigem que o intérprete vá consideravelmente além do texto de Aristóteles. Ao fim do percurso, não espero mostrar que as interpretações baseadas em T são inviáveis, mas que não podem ser adotadas sem um custo considerável.

\section{Questões acerca do preservacionismo}

Com esse objetivo em vista, procederei primeiramente a um exame do traço preservacionista que que $\mathrm{T}$ atribui ao método. Como visto na seção precedente, na leitura

\footnotetext{
${ }^{53}$ As evidências de que Aristóteles está buscando uma certa verdade na ética abundam. Por exemplo, por meio da phronêsis, o bom agente tem uma apreensão verdadeira do fim da ação (EN VI 9, 1142b32-33). São também notáveis a esse respeito as oposições entre o que verdadeiramente ou por natureza é bom, mal, prazeroso, temível etc. e o que é assim apenas na aparência ou para alguém (EN IV 9, 1128b23; EE III 1, 1228b17-22; EE VIII 3, 1248b26 ss.)
} 
T, o exame de aporias mencionado na parte B de [2] é compreendido como identificação de incompatibilidades entre os endoxa coligidos em $\Delta_{\mathrm{i}}$. A formação de $\Delta_{\mathrm{f}}$, por sua vez, demandaria a solução dos conflitos, preservando tanto quanto possível as opiniões do conjunto inicial. A questão que nos ocupará agora diz respeito a determinar sob que condições essa tarefa que a leitura T dispõe no coração do método de Aristóteles deve ser executada.

Em alguns casos, a formação de $\Delta_{\mathrm{f}}$ certamente demandará a eliminação de itens de $\Delta_{\mathrm{i}}$. Supondo, por exemplo, que a consistência de $\Delta_{\mathrm{i}}$ seja impedida apenas e tão somente pela presença em $\Delta_{\mathrm{i}}$ de uma opinião $\delta_{\mathrm{n}}$, que é incompatível com os demais membros de $\Delta_{\mathrm{i}}, \Delta_{\mathrm{f}}$ poderia ser obtido pela exclusão de $\delta_{\mathrm{n}}$ do conjunto original.

A leitura T, no entanto, encontra em [2] um método de natureza acolhedora, buscando preservar, se não todas as opiniões contidas em $\Delta_{\mathrm{i}}$, ao menos "a maioria e as principais". Supostamente, portanto, antes de se eliminar uma opinião, deve-se verificar se há outros recursos para formar o conjunto consistente $\Delta_{\mathrm{f}}$. Aqui a interpretação que parte de $\mathrm{T}$ deverá lançar mão do fato inequívoco que, seja qual for a importância dos endoxa, Aristóteles frequentemente os altera significativamente para encontrar uma afirmação que ele tome como verdadeira. Incorporando-se tal fato às interpretações que partem de $T$, tem-se que a busca pela consistência incluirá não apenas a eventual eliminação de opiniões, mas também a reformulação (por vezes radical) de opiniões contidas no conjunto inicial.

À primeira vista, esse fato não parece criar problemas para a interpretação tradicional. Com efeito, tendo apresentado um conflito entre opiniões, Aristóteles não raro afirma que o conflito se resolve compreendendo que de um modo é verdadeira uma das opiniões e, de outro modo, é verdadeira a outra. ${ }^{54}$ Isso sugere que a reformulação de opiniões está em consonância com o traço preservacionista que T atribui ao método.

Alguns dos recursos reconhecidos como meios de reelaborar as opiniões iniciais tratam diretamente da linguagem na qual foram originalmente formuladas as opiniões. ${ }^{55}$

${ }^{54}$ Ver, por exemplo: EN VI 13, 1144b17-21; EN VIII 14, 1163b1; EE VII 2, 1235b16-18, $1236 \mathrm{~b} 21-26$, etc..

${ }^{55}$ Stewart (1892, p. 122), por exemplo, entende que as aporias identificadas no conjunto das opiniões coligidas devem-se, em sua maioria, "às ambiguidades da linguagem comum" (em direção semelhante segue Kraut : 2006, p. 81). Uma vez que a atenção aos vários modos pelos quais algo é dito é tema central em Tópicos I 14-18, Stewart toma esse conjunto de textos como uma exposição expandida do método condensado em EN VII 1. Note-se, no entanto, que, ao tratar do exame dos termos de muitos sentidos, Tópicos I 18 deixa claro que o procedimento é, ali, abordado em vista de sua importância para o debate dialético, uma vez que por meio dele evitase que os debatedores tenham assuntos distintos em mente ao empregar palavras idênticas (ver 
Em certos casos, pode-se desfazer um impasse mostrando que a incompatibilidade entre as opiniões $\delta_{\mathrm{n}}$ e $\delta_{\mathrm{x}}$, diferentes entre si, decorre do fato que um mesmo termo é empregado com sentidos distintos em cada uma delas. Em casos simples, quando o conflito se deve pelo uso evidente de um mesmo termo com sentidos claramente diversos, diríamos que o impasse é meramente aparente - o que estaria plenamente de acordo com o traço preservacionista da leitura T. No entanto, os procedimentos que Aristóteles aplica sobre opiniões reputáveis com vistas a encontrar nelas uma afirmação verdadeira frequentemente envolvem a introdução de distinções sofisticadas ${ }^{56}$ ou mesmo uma grande alteração no sentido dos termos empregados ${ }^{57}$ Em outros casos, ainda que o sentido dos termos empregados nas opiniões originais não seja alterado, a resolução do conflito recorre à inclusão de cláusulas adicionais que especificam, restringem ou mesmo alteram o âmbito de aplicação das opiniões. ${ }^{58}$

Qualquer interpretação que parta de T, portanto, precisa aceitar que frequentemente a suposta preservação das opiniões de $\Delta_{\mathrm{i}}$ em $\Delta_{\mathrm{f}}$ dá-se pela aceitação de uma versão transformada da crença original. O conjunto final $\Delta_{\mathrm{f}}$ não incluirá exatamente $\delta_{\mathrm{n}}$ e $\delta_{\mathrm{x}}$, mas suas versões $\delta_{\mathrm{n}}{ }^{*}$ e $\delta_{\mathrm{x}}{ }^{*}$, que poderão corresponder às opiniões iniciais reinterpretadas ou adicionadas de cláusulas qualificadoras.

Suponhamos, agora, que seja possível resolver um conflito em $\Delta_{\mathrm{i}}$ ou bem pela eliminação de uma opinião ou bem pela reformulação de duas outras. Qual seria a opção mais apropriada do ponto de vista acolhedor do procedimento que a leitura $\mathrm{T}$ encontra em [2]? O caráter generoso e conservador do método impõe que $\Delta_{\mathrm{i}}$ seja tão pouco alterado quanto possível. Não é claro, no entanto, qual das duas alternativas seria mais conservadora: solucionar o conflito eliminando uma opinião e mantendo as duas outras em sua formulação original ou preservando a primeira e substituindo as demais por suas versões reformuladas. A solução não é simples, uma vez que a reformulação das opiniões iniciais pode alterá-las de modo muito significativo. Não é, de maneira alguma evidente

Top. I 18, 108a20ss.). Não é de modo algum claro que tais observações pretendam ter aplicação para além do âmbito dos debates dialéticos.

${ }^{56}$ Trata-se, por exemplo, do recurso à distinção entre sentidos de "conhecer" que se encontra em EN VII 3, 1146b31-35.

${ }^{57}$ É o caso da discussão que se dá na Ética Eudêmia a respeito da opinião de Sólon segundo o qual não se deve proclamar a felicidade de alguém antes que a sua vida "atinja a completude" (EE II 1, 1219b6-8). Trata-se de caso que será discutido adiante.

${ }^{58}$ Trata-se do caso relativo ao tratamento dado às opiniões reputáveis sobre a amizade em Ética Eudêmia VII, que será discutido adiante. 
que a opção de formar $\Delta_{\mathrm{f}}$ a partir de versões reformuladas de duas opiniões e evitando a exclusão uma terceira seja mais preservadora do que a alternativa que se limita a excluir essa última mantendo as duas primeiras em sua versão original.

Evidentemente, o problema exige que se considere a natureza das opiniões em questão e das alterações adotadas nas versões reformuladas. Em EN VII 1, 1145b6, Aristóteles sugere que algumas opiniões são mais importantes (ta kuriôtata) ou têm mais autoridade do que outras. O critério de importância e autoridade poderia fazer a balança pender decisivamente para uma das duas alternativas em detrimento da outra. Por exemplo, se a opinião única cuja exclusão está sob consideração corresponde àquela segundo a qual a felicidade é o maior e o melhor dos bens humanos, não há o que autorize a sua eliminação do conjunto final. A grande maioria das alterações que poderiam ser executadas sobre $\Delta_{\mathrm{f}}$ seria preferível à sua exclusão.

O critério de autoridade é de fácil aplicação quando se trata, como nesse exemplo, de opiniões que são evidentemente fundamentais no âmbito da investigação que as examina. No entanto, Aristóteles não apresenta em lugar algum um critério claro para determinar quais opiniões têm mais autoridade do que quais outras. Sem um tal critério, não se pode eliminar a possibilidade de um impasse entre soluções alternativas de uma mesma aporia. Mesmo dispondo de tal critério, contudo, o impasse pode surgir. Se a inconsistência pode ser solucionada ou bem pela eliminação de $\delta_{n}$ ou bem pela eliminação de $\delta_{\mathrm{x}}$, tendo ambas o mesmo grau de autoridade, o método não permite distinguir se a boa solução seria a eliminação dessa ou daquela opinião. Do ponto de vista da generosidade e do preservacionismo do método, as duas estão em pé de igualdade. ${ }^{59}$

O mesmo problema se repete com relação às soluções que recorrem à reformulação de opiniões em conflito. Frequentemente, há diferentes maneiras de fazer com que duas opiniões inicialmente incompatíveis sejam ambas verdadeiras, cada uma a seu modo. Suponhamos que $\delta_{\mathrm{n}}$ enuncie que "S é P" e que $\delta_{\mathrm{x}}$ enuncie precisamente que "S não é P". Seria possível manter conjuntamente $\delta_{\mathrm{n}}$ e $\delta_{\mathrm{x}}$, por exemplo, introduzindo qualificações temporais ou qualificações quanto ao aspecto considerado. No primeiro caso, dir-se-ia que "S é P" é verdadeiro no momento $t_{1}$ e que "S não é P" é verdadeiro no momento

\footnotetext{
${ }^{59}$ Sobre as dificuldades concernentes à aplicação do critério de autoridade no âmbito do "método dialético", ver Irwin : 1988, p. 45-47.
} 
posterior $t_{2}$. No segundo caso, seria dito que "S é P" é verdadeiro com relação a $x$, ao passo que "S não é P" é verdadeiro com relação a $y{ }^{60}$

De um modo geral, as inconsistências de um conjunto de endoxa poderão ser solucionadas por inúmeras vias. Um conjunto consistente poderá ser formado por diversas combinações de eliminações pontuais e reformulações. Em muitos casos, será difícil, quando não impossível, determinar qual das combinações melhor preserva o conjunto inicial.

Essas questões precisam ser resolvidas por todo intérprete que pretenda basear em T uma concepção do método aristotélico. É possível propor soluções para tais questões (e várias encontram-se sugeridas na literatura). No entanto, as soluções propostas excedem consideravelmente o que o próprio Aristóteles afirma sobre o tema. Com efeito, o fato que tais problemas não se encontram nem mesmo formulados em suas obras coloca em questão a importância que se possa atribuir a um método baseado na leitura T. Se tal leitura permanece uma alternativa plausível (e mesmo atraente) para a compreensão de [2], o silêncio de Aristóteles sobre as questões apresentadas sugere que a importância do procedimento extraído daquele texto é bastante limitada.

\section{O preservacionismo e a prática de Aristóteles}

Para além dessas questões de caráter geral, cabe perguntar se a prática efetiva de Aristóteles (ou seja, o tratamento por ele dispensado aos endoxa nos tratados de ética) está, de fato, em consonância com as características que a leitura $\mathrm{T}$ atribui ao método. Uma discussão exaustiva dos textos pertinentes excederia em muito os limites deste trabalho. No entanto, um breve exame de casos é suficiente para indicar que as evidências a esse respeito podem ser consideravelmente resistentes às interpretações que se baseiam em T.

Em EN VI 13, 1144b17-28, por exemplo, Aristóteles deixa claro que encontra algo de verdadeiro na opinião de Sócrates segundo a qual todas as virtudes seriam sabedorias práticas (phronêseis). Ao fim do exame, Aristóteles retém da tese socrática uma versão

\footnotetext{
${ }^{60}$ Burnet considera que os topoi expostos nos Tópicos constituem uma variedade de ferramentas pelas quais se pode adicionar qualificações a crenças em conflito de modo a desfazer os impasses: "Eles [os topoi da dialética] são, de fato, uma variedade de modos pelos quais as crenças sob discussão podem ser qualificadas, de modo que a contradição, que apenas surge pelo fato que elas [as crenças] foram enunciadas sem qualificação, irá desaparecer." (1900 : p. xli).
} 
muito mais fraca da relação entre virtude e sabedoria prática: é verdadeiro que não há virtude sem phronêsis, mas não que todas as virtudes devam ser compreendidas como sabedorias práticas. Ainda que haja, evidentemente, uma relação entre a tese de partida e a tese mantida ao final do exame e que, quanto à formulação, as duas sejam semelhantes, a segunda tese expressa uma concepção muito diferente da primeira acerca da natureza da virtude. Se essa alteração resulta da intenção de manter tanto quanto possível a tese inicial, ela parece pouco fiel ao seu propósito.

Já em EE II 1, 1219b6-8, Aristóteles apresenta uma breve análise do dito de Sólon segundo o qual não se deve proclamar a felicidade de alguém antes que a sua vida "atinja a completude" (hotan labê(i) telos: 1219b7). Em tal análise, que difere significativamente daquela dedicada ao mesmo dito em EN I 10, Aristóteles concede certa razão a Sólon, uma vez que nada incompleto (outhen gar ateles: 1219b7) pode ser considerado feliz. No entanto, o sentido de completude envolvido no dito de Sólon é distinto do que é relevante para Aristóteles. Uma vida "completa", no sentido do dito, é uma vida que já chegou a seu termo - por isso, segundo Sólon, não se deve proclamar a felicidade de alguém enquanto vive (1219b7). Aristóteles, por contraste, tem em mente a completude relativa à realização plena do tipo de vida próprio do ser humano (razão pela qual a felicidade está associada ao exercício da excelência própria do ser humano). Essa condição depende de certo decurso de tempo para ser satisfeita, mas nada impõe que sua satisfação só possa ser avaliada acerca de uma vida que já se encerrou. Novamente, o resultado deixa transparecer pouca preocupação com a preservação do espírito do dito inicial.

Outro caso revelador pode ser encontrado na discussão sobre a amizade que tem lugar em EE VII. Naquele texto, Aristóteles discute duas posições rivais com relação à natureza da amizade. De acordo com a primeira, "o semelhante é amigo do semelhante" (1235a56), ao passo que a segunda enuncia que "os opostos são amigos" (1235a25).

À primeira vista, esse caso parece favorecer a interpretação T. As posições discutidas correspondem evidentemente a endoxa, sendo atribuídas, respectivamente, a Empédocles e Heráclito. Além disso, elas estão associadas a uma passagem que faz ressoar fortemente o texto [2]:

[3] Deve-se adotar a explicação [logos] que ao mesmo tempo nos apresente de melhor modo as opiniões [ta dokounta] sobre esses assuntos e solucione as aporias e oposições. Isso ocorrerá se as opiniões contrárias revelarem-se razoáveis. Com efeito, tal explicação concordará sobretudo com o que é manifesto [ta phainomena]. As oposições calharão de permanecer [menein], se o que é dito for, de um modo, verdadeiro e, de outro, não. (EE VII 2, 1235b13-18) 
O texto [3] (provavelmente a passagem do corpus que está mais próxima de [2]) expõe um procedimento que parte de opiniões opostas e busca expô-las adequadamente, solucionando as dificuldades. Seu ponto final se dá com a permanência (menein) das opiniões iniciais no registro "verdadeiro de um modo, de outro, não". Além de operar sobre endoxa, o procedimento parece compartilhar do preservacionismo que desponta de [2] a partir da leitura $\mathrm{T}$.

No entanto, aqui também cabe questionar quanto foi mantido das opiniões iniciais. Em EE VII 5, onde as posições conflitantes sobre a amizade são resgatadas, elas não ressurgem como teses gerais sobre a amizade, mas como teses de aplicação restrita. Tendo estabelecido que há amizade pela virtude, pelo prazer e pela utilidade, Aristóteles conclui que a noção de semelhança se aplica apenas aos dois primeiros tipos, ao passo que a oposição é pertinente apenas ao terceiro. Amigos segundo a virtude são semelhantes porque o que é bom é semelhante a si próprio (1239b16-17). A semelhança também se aplica à amizade pelo prazer porque a mesma coisa é prazerosa para pessoas semelhantes (1239b17-20). Finalmente, os opostos são amigos segundo a amizade pela utilidade, uma vez que o semelhante é inútil ao que é semelhante (1239b23-25).

Pode parecer que o preço, neste caso, não foi excessivo: de cada lado da disputa perdeu-se uma tese geral sobre a amizade, mas se manteve uma tese sobre um ou dois tipos de amizade. No entanto, a primeira observação que Aristóteles faz sobre as opiniões em questão é que seu escopo é excessivamente amplo (EE VII 1, 1235a4-5). Os modelos da semelhança e da oposição reduzem a um mesmo padrão relações humanas de amizade e relações que se dão entre seres não-humanos, como aquelas entre animais, entre as coisas úmidas e secas e entre os tons que formam as harmonias musicais (1235a5-29). É bem possível que essa amplitude de escopo que Aristóteles considera inaceitável estivesse no centro dos projetos que produziram as opiniões discutidas. De fato, é possível que objetivo dos seus proponentes fosse justamente o de fornecer um padrão geral para a compreensão da natureza que abarcasse tanto as relações humanas, como também as relações entre seres não-humanos (ver 1235a10-11). Nesse caso, a "manutenção" da tese original ao final da análise passa pela completa recusa do projeto original como inadequado (1235a4-5). Desse modo, aos proponentes das teses iniciais, a preservação de suas opiniões deveria parecer muito decepcionante.

Expressando de maneira eloquente o traço preservacionista que T encontra em [2], Nicholas Denyer compara a constituição de $\Delta_{\mathrm{f}}$ a partir de $\Delta_{\mathrm{i}}$ à elaboração de um tratado negociado entre as diferentes partes envolvidas (Denyer : 1991, p. 210). Essa imagem, 
que capta bem um aspecto fundamental da leitura tradicional, parece chocar-se com o que se encontra nas obras éticas. De fato, considero excessivamente otimista o juízo de Denyer sobre o efeito que o resultado da "negociação" conduzida por Aristóteles teria sobre os proponentes das opiniões iniciais: "Uma vez que todas as partes serão capazes de reconhecer nessa síntese [a que corresponde à formulação de $\Delta_{\mathrm{f}}$ a partir de $\Delta_{\mathrm{i}}$ ] uma enunciação das verdades que estavam sugerindo e uma explicação de qualquer falsidade na qual possam ter incorrido, essa síntese deve impor o assentimento universal" (1991, p. 210). Creio que a descrição de Pritzl seja mais acurada a esse respeito: "Em muitos casos, quando Aristóteles explica o modo pelo qual a máxima de um sábio ou um endoxon da multidão é verdadeiro, ele fornece uma explicação que a multidão ou mesmo o sábio poderiam não reconhecer ou subscrever" (1994, p. 46-47). Com efeito, não creio que Sócrates, Sólon, Empédocles e Heráclito fossem concordar que suas opiniões tenham sido em qualquer medida aceitável mantidas ao final do exame de Aristóteles.

\section{A introdução das posições de Aristóteles}

O conservadorismo que $\mathrm{T}$ atribui ao procedimento de [2] impõe que se evite de incluir em $\Delta_{\mathrm{f}}$ qualquer tese que não esteja contida em $\Delta_{\mathrm{i}}$. Essa característica, no entanto, também contrasta com a prática de Aristóteles. Via de regra, parte importante das crenças que receberão o assentimento de Aristóteles ao final de uma pesquisa será composta de teses propriamente aristotélicas, que não estão necessariamente incluídas num conjunto de opiniões reputadas. Trata-se, usualmente, de teses teoricamente comprometidas, decorrentes das investigações de Aristóteles.

Assim como no caso anterior, um exame completo das evidências a esse respeito cobriria extensão considerável. Aqui também limitarei a discussão à indicação de umas poucas evidências que creio serem suficientes para colocar em dúvida o traço que a interpretação tradicional atribui ao método.

Um caso significativo diz respeito ao recurso à noção de ergon que é aplicada à alma humana em EE II 1 e ao ser humano como um todo em EN I 7. Frequentemente traduzida por "função" (tradução usual, mas em boa medida inadequada), essa noção desempenha um papel decisivo no estabelecimento da definição da felicidade tanto na Ética Nicomaqueia, como na Eudemia. Seu uso nos argumentos das duas obras está estreitamente vinculado ao essencialismo aristotélico e, portanto, às suas teses metafísicas. 
Outro exemplo a esse respeito corresponde à compreensão da alma humana como divisível em duas partes, racional e irracional, sendo a segunda parte novamente divisível entre a parte irracional que é capaz de ouvir o mando da razão e a parte que é incapaz de fazê-lo. Essa concepção da alma é fundamental para a concepção aristotélica da ação e da virtude humana e é introduzida como desenvolvimento propriamente aristotélico. $\mathrm{Na}$ Ética Nicomaqueia, Aristóteles remete o desenvolvimento dessa concepção aos seus trabalhos "exotéricos" (ver EN I 13, 1102a26-27). Na Ética Eudêmia, por sua vez, a apresentação da mesma concepção é antecedida da expressão hypokeisthô ("que fique assumido"; ver EE II 1, 1219b28), que caracteriza a introdução de uma hipótese de trabalho (frequentemente desenvolvida alhures). ${ }^{61}$

Também se pode fornecer como exemplo a esse respeito o recurso que Aristóteles faz a sua doutrina das categorias. Com base nela, a teoria platônica do bem é atacada em Ética Nicomaqueia I 6 e em Ética Eudêmia I 8.

A meu ver, um caso muito revelador corresponde ao recurso que Aristóteles faz às suas concepções acerca do que se admite como explicação apropriada. Com efeito, ele recorre às suas teses a esse respeito como um critério para avaliar endoxa nas discussões sobre a amizade que têm lugar no livro VII da Ética Eudêmia e no VIII da Nicomaqueia. Em ambas obras, as posições endoxais opostas que examinei na seção anterior, segundo as quais a amizade deve ser compreendida com base na semelhança ou com base na oposição são recusadas a partir de teses aristotélicas sobre o que conta como uma boa explicação em cada contexto. Em EE VII 1, Aristóteles afirma que tais teses são excessivamente gerais e extrínsecas ao tema da amizade (elas são ditas serem opiniões de hoi exôthen perilambanontes kai epi pleon legontes: EE VII 1, 1235a4-6). A meu ver, Aristóteles está recorrendo às teses sobre a extensão apropriada das explicações em relação aos seus explananda que podem ser encontradas nos Segundos Analíticos (por exemplo, Seg. An. I 7 e 9; ver 76a4-7).

Ainda que o texto da Ética Nicomaqueia seja mais discreto com relação às razões que levam Aristóteles a recusar as teses endoxais sobre a amizade, ele afirma que tais opiniões não são apropriadas (oikeia) à investigação em curso (EN VIII 2, 1155b8-9;

${ }^{61} \mathrm{O}$ fato que Aristóteles provavelmente tenha desenvolvido tal concepção a partir de teses platônicas (ver Dirlmeier : [1963] 1984, p. 232) não interfere no ponto. O que importa, no presente contexto, é que tal concepção não é introduzida como tese platônica (o que, ao menos em princípio, permitiria tomá-la como uma das opiniões reputáveis), mas sim como tese que é defendida em voz própria. 
1155b1-2). Trata-se, creio, de um raciocínio que segue na mesma direção daquele apresentado na Eudêmia e que lança mão das concepções de Aristóteles sobre as explicações apropriadas (oikeion).

Defensores de versões da intepretação tradicional sustentarão que essas teses (várias delas, ao menos) são elas próprias defendidas em outros contextos de maneira dialética. Novamente, não há como excluir definitivamente uma tal hipótese. No entanto, quando Aristóteles recorre a elas em seus trabalhos de ética não há qualquer menção acerca de sua origem dialética ou endoxal. Tampouco a introdução de tais teses nas obras éticas é acompanhada de qualquer indicação de que Aristóteles acredita que, ao introduzilas, está respeitando o preservacionismo e o conservadorismo que a leitura tradicional atribui ao método. A esse respeito, seu o procedimento sugere antes que ele concede maior autoridade e importância às suas próprias teses do que aos endoxa.

Diante da frequência com que Aristóteles recorre a seus resultados teóricos, alguns autores sugerem que as teses do próprio Aristóteles devam ser tomadas como endoxa. Nesse caso, por mais exóticas que as soluções adotadas por Aristóteles pareçam aos demais (quer se trate de sábios e filósofos, quer da comunidade geral), o conjunto final $\Delta_{\mathrm{f}}$ será sempre fundamentalmente composto por opiniões reputadas em sua formulação geral ou retrabalhadas.

Essa estratégia baseia-se na compreensão do próprio investigador que se dedica às questões éticas (Aristóteles entre eles) como um dos sábios mencionados na delimitação do escopo de endoxa exposta em Top. I 1, 100b21-23I 1 (ver, por exemplo, Kraut : 2006, pp. 91-93). Essa sugestão, no entanto, esvazia de sentido a noção de endoxon. A inclusão do próprio pesquisador no âmbito dos sábios reputáveis cuja opinião conta como endoxon é incompatível com a ideia de boa reputação - de reputação já estabelecida - que é própria do termo. ${ }^{62}$

Seria também possível tentar acomodar a introdução de teses próprias no método de EN VII 1 a partir da ideia segundo a qual tais teses sejam introduzidas com vistas a criar o conjunto consistente de opiniões que deve corresponder à síntese final. Nessa perspectiva, as teses de Aristóteles teriam o objetivo de estabelecer as pontes entre as opiniões inicialmente divergentes (ainda que o assentamento dessas pontes em cada uma das margens opostas exija certa reformulação das opiniões iniciais). No entanto, mesmo que fosse possível descrever desse modo os muitos casos nos quais Aristóteles introduz

${ }^{62}$ Para uma argumentação que segue nessa direção, ver Frede (2012, p. 192). 
teses próprias em sua reflexão ética, há um limite para o uso desse recurso no método dos endoxa. Para que a solução funcione no marco desse modelo, as teses próprias (ou ao menos um número considerável delas) teriam que ser formuladas sob medida para servir como pontes entre as opiniões a serem assimiladas ao modelo final. No entanto, parece ocorrer antes o contrário: Aristóteles está mais disposto a alterar as opiniões reputáveis com vistas a torná-las compatíveis com as suas teses do que o inverso.

\section{Alternativas que buscam resguardar a leitura tradicional}

Os defensores da hipótese tradicional podem encontrar soluções para as limitações aqui apontadas. De fato, a literatura apresenta várias soluções para as dificuldades elencadas. Kraut, por exemplo, sustenta que EN VII 1 apresenta apenas parte do método. Para a efetiva utilização do procedimento lá descrito, as crenças preservadas precisariam ser dispostas em uma "ordem arquitetônica", de modo que as teses mais fundamentais forneçam apoio para as demais crenças. Esse arranjo seria, então, testado a partir da experiência (Kraut : 2006, p. 87-93).

Uma proposta ainda mais radical é a célebre tese de Irwin (1988), que sofistica consideravelmente a leitura $\mathrm{T}$ a partir da adoção de um critério de distinção entre endoxa ordinários e endoxa de caráter especial. Partindo dos primeiros, o método não seria capaz de estabelecer mais do que um conjunto consistente de opiniões. Ao partir dos segundos, no entanto, o método resultaria na "dialética forte", capaz de estabelecer os primeiros princípios que são supostos por uma certa disciplina.

Barnes também propõe a adoção de hipóteses adicionais para dar conta do que seriam limitações excessivas do método dos endoxa (1980, p. 501-502). Para evitar as limitações do conservadorismo do método tal como interpretado pela hipótese tradicional, Barnes propõe que não se incluam entre os endoxa apenas crenças expressamente enunciadas. Também seriam endoxa as teses que são decorrências diretas ou corolários das crenças expressas, assim como as "crenças latentes na linguagem". Finalmente, também contariam como endoxa as crenças que podem ser atribuídas a um agente por meio de suas ações e escolhas, a despeito de não terem sido por ele expressamente 
enunciadas. Ao fim e ao cabo, Barnes dirá que é notável quão poucas proposições não podem ser incluídas em $\Delta_{\mathrm{i}}(1980$, p. 510$) .{ }^{63}$

Outra alternativa é proposta por Berti para quem o procedimento exposto em [2] consiste fundamentalmente na demonstração de que uma certa tese (que ele inclui entre os phainomena, mas não entre os endoxa) é compatível com a totalidade ou a maioria dos endoxa, acompanhada de uma demonstração complementar da incompatibilidade da tese oposta à que se deseja estabelecer em relação, novamente, à totalidade ou maioria dos endoxa ([1995] 2010, p. 322-324).

Estratégias como essas, que foram aqui mencionadas a título de exemplo, buscam preservar a hipótese tradicional por meio de sua inclusão em uma compreensão mais ampla do método aristotélico. O texto de Aristóteles não veda diretamente a adoção de tais hipóteses. De fato, a passagem de EN VII 1, 1145b2-7, bem como os demais textos de teor metodológico que a ela costumam ser associadas ${ }^{64}$ são suficientemente vagos para que os defensores de versões da leitura tradicional considerem razoável a adoção de hipóteses adicionais para substanciar a sua compreensão. Com efeito, algumas das limitações apontadas, em isolado, certamente seriam insuficientes para abalar a hipótese tradicional. Seria, por exemplo, possível argumentar que a adoção de uma hipótese adicional semelhante àquela proposta por Barnes não impõe nenhuma alteração fundamental na compreensão do método. Ao sustentar que o domínio dos endoxa não é restrito às crenças expressamente enunciadas, Barnes pode afirmar que está apenas explorando o traço conservador do método de modo a torná-lo compreensível à luz da prática de Aristóteles.

A meu ver, no entanto, tomadas em conjunto, as dificuldades apontadas colocam sob considerável suspeição a proposta de tomar a leitura $\mathrm{T}$ de [2] como base para uma interpretação de amplo escopo. Com isso, torna-se razoável explorar outras alternativas para a compreensão de [2] e do método da ética de Aristóteles em geral. A seguir, apresentarei em suas linhas gerais uma proposta a esse respeito.

${ }^{63}$ Curiosamente, no parágrafo anterior da mesma página, Barnes ressalta o caráter restritivo do método, afirmando que ele impede a consideração de certas proposições como portadoras de verdade (1980, p. 510).

${ }^{64}$ Além de EE VII 2, 1235b13-18 (o texto [3] deste trabalho), as seguintes passagens são usualmente relacionadas ao esboço metodológico que se encontra em [2]: EN 1145b3-5, 1146b68; EE 1214a12, 1215a5-7, 1216b26-35; Física 211a7-11; De Anima 403b20-24; Metafísica, 995a24-b4. 


\section{Proposta de uma alternativa interpretativa}

A passagem [2] ocorre na introdução da discussão nicomaqueia sobre continência e incontinência que ocupa os dez primeiros capítulos de EN VII. É controversa a medida na qual Aristóteles se mantém fiel ao procedimento descrito em [2] ao desenvolver a investigação de EN VII 1-10 e são muito discutidos os detalhes do modo como o procedimento é efetivamente aplicado. ${ }^{65}$ Ainda que seja inviável realizar aqui uma análise pormenorizada de EN VII 1-10, será necessário recorrer a alguns elementos da discussão que é lá desenvolvida para propor os pontos centrais de uma interpretação alternativa para o procedimento exposto em [2].

Desse modo, gostaria de começar notando um problema que surge quando se assume que i) há uma correspondência entre os phainomena de $1145 \mathrm{~b} 3$ e os endoxa de $1145 \mathrm{~b} 5$ e ii) compreende-se que, ao falar de endoxa em [2], Aristóteles tem em mente todas as opiniões sobre o tema que caem sob a delimitação extensional de Top. I 1, 100b21-23. De acordo com a delimitação estabelecida no início dos Tópicos, a opinião dos sábios deve contar como endoxa, o que confere caráter endoxal às posições de Sócrates. No entanto, a tese socrática segundo a qual ninguém age contrariamente ao que considera ser o melhor (da qual se segue que não há incontinência) é dita conflitar "evidentemente com os phainomena" (1145b28). ${ }^{66}$ Isso cria uma flagrante tensão entre as suposições i) e ii). ${ }^{67}$

Para tratar do problema, proponho desfazer a estrita correlação phainomena e endoxa e sugerir que, das duas noções, é a primeira que desempenha o papel mais fundamental na passagem. Na ética, assim como em outros contextos, são phainomena as evidências a partir das quais deve desenvolver-se a investigação. ${ }^{68}$ Em filosofia prática,

${ }^{65}$ É notável a discordância entre os intérpretes a esse respeito. Stewart admite que o método é seguido de forma "não muito sistemática" por Aristóteles em EN VII 1-10 (1892, v. II, p. 122). Pakaluk sustenta que precisamente esse conjunto de textos segue "exatamente" o plano esboçado em EN VII 1, 1145b2-7 (2005, p. 235). Em direção semelhante à de Stewart, ver Cooper (2009, p. 29-39; em especial, p. 37-39) e Frede (2012, p. 210-213).

${ }^{66}$ Em 1145b28, tomo enargôs como qualificando amphisbêtei ("conflita evidentemente com os phainomena") e não como qualificando tois phainomenois ("conflita com o que manifestamente parece ser o caso").

${ }^{67}$ A mesma tensão pode ser vista na discussão eudêmia da amizade, onde a opinião platônica segundo a qual apenas a amizade segundo a virtude é amizade genuína é dita fazer violência aos phainomena (1236b21-22; ver também 1236a25-26).

${ }^{68}$ Ver, por exemplo, EE I 6, 1216b26-35 e Primeiros Analiticos I 30, 46a17-24. 
os phainomena típicos são endoxa porque as opiniões que gozam de boa reputação tendem a revelar as crenças fundamentais que orientam as relações entre os seres humanos. ${ }^{69}$ A ideia de reputação que está no coração da noção de endoxon, no entanto, é relativa. Algo é reputado não em si mesmo, mas para alguém e em certo contex to ${ }^{70}$ Certas opiniões são, por exemplo, reputadas para os filósofos ou cientistas, mas não para o público geral. Diante disso, minha sugestão é que, a despeito da reputação da qual possa gozar a opinião de Sócrates em certos âmbitos, ela não possui o tipo de reputação que a qualifica como um phainomenon na discussão sobre continência e incontinência. ${ }^{71}$ De fato, ela não corresponde ao tipo de opinião no qual as pessoas usualmente baseiam seus juízos e atitudes a esse respeito e, desse modo, não constitui uma evidência adequada para dar início à investigação sobre o tema.

Ao falar de "todas as opiniões reputáveis sobre essas afecções" em 1245a4-5, portanto, Aristóteles estaria fazendo referência à totalidade das opiniões que, por gozarem de certo tipo de reputação, qualificam-se como phainomena sobre o assunto. É bem possível que nesse contexto apenas opiniões de grande aceitação estejam sendo tomadas como tal. Trata-se paradigmaticamente (ainda que não exclusivamente) das opiniões que são apresentadas ao fim de EN VII 1 e cuja exposição é encerrada com a observação “essas, então, são as coisas ditas" (1145a20). ${ }^{72}$

${ }^{69}$ Os endoxa, no entanto, não esgotam o domínio dos phainomena da ética. Entre eles estão incluídos também, por exemplo, erga ou ações, cuja apreensão pelo pesquisador se dá de modo semelhante à coleta de evidências empíricas: ver EE VII 12, 1245a26 e EN X1, 1172a34-b1.

${ }^{70}$ Ver Smith (1993, p. 343-349; 1997, p. xxiii-xxiv; 1999, p. 44-47) e Brunschwig (1967, p. $113-$ 114).

${ }^{71}$ Cooper entende que a opinião é Sócrates é tomada como endoxon, mas não como phainomenon. Para ele, apenas opiniões diretamente sobre continência e incontinência ou sobre as pessoas que são portadoras de tais traços de caráter contam como phainomena no contexto (2009, p. 24-25).

${ }^{72}$ Aristóteles claramente entende que as opiniões expostas ao final de EN VII 1 não esgotam os phainomena sobre o assunto. Em EN VII 2, 1146b5, por exemplo, há a introdução de um endoxon adicional de acordo com o qual "dizemos que algumas pessoas são incontinentes sem qualificação". Quanto à sugestão segundo a qual os endoxa relevantes no contexto correspondem a opiniões de grande aceitação, Cooper $(2009$, p. 26) observa que, dentre as opiniões listadas ao final de EN VII 1, aquela segundo a qual há incontinência com respeito à ira, à honra e ao ganho material (1145b19-20) pode ser relacionada a pensadores notórios como Platão, Xenofonte e Isócrates. Note-se, no entanto, que em EE II 7 a existência da incontinência quanto à ira é introduzida simplesmente por um dokei (1223b18-19). Assim, mesmo que tais opiniões possam ser associadas aos pensadores mencionados por Cooper, pode não ser o caso que Aristóteles as tome como opiniões de sábios em contraste com o uso comum. 
Assim, ao adotar uma posição que é incompatível com a realidade da incontinência, Sócrates não estaria expressando algo que, no contexto, deve ser tomado como opinião reputável nem como phainomenon. Isso, evidentemente, tem consequências consideráveis para a compreensão do que está ocorrendo na discussão nicomaqueia sobre a incontinência. Com efeito, a partir dessa proposta, o capítulo fundamental EN VII 3 (onde Aristóteles articula o núcleo de sua compreensão sobre o tema) deixa de ser entendido à maneira da leitura tradicional como parte de um esforço para manter uma opinião reputável (a de Sócrates) no conjunto das teses aceitas. De fato, entendo que naquele texto Aristóteles não esteja tentando salvar a opinião de Sócrates, mas expondo suas próprias teses sobre o assunto. Nesta perspectiva, a tese socrática não é mencionada por ser um endoxon que deve ser retido, mas porque traz à baila um aspecto da questão que parece relevante a Aristóteles, a saber, as relações entre a ação incontinente e a posse do conhecimento.

A tese de Sócrates é introduzida em EN VII 2, 1145b23-27, no capítulo que expressamente desenvolve as aporias sobre o tema da investigação e, portanto, executa a etapa do método que é exposta no trecho B de [2]. Esse fato é usualmente tomado como indicação de que Aristóteles toma a opinião de Sócrates como endoxon, a despeito da expressa afirmação sobre seu conflito com os phainomena. Com efeito, na interpretação tradicional, o exame de aporias corresponde ao desenvolvimento de raciocínios que estão na base de endoxa incompatíveis entre si. Quero, agora, justamente apresentar uma compreensão alternativa para essa segunda etapa do procedimento exposto em [2].

Para tanto, lançarei mão do modo como Irwin e Owen entendem a diferença entre o papel que as aporias teriam no método das ciências empíricas e no método dialético que, na sua compreensão, seria apropriado para disciplinas como a ética. De acordo com a interpretação daqueles autores, no contexto dialético uma aporia exige que se identifique qual de duas proposições conflitantes é verdadeira e qual é falsa. Desse modo, a aporia será desfeita pela eliminação de uma das teses que a geram do conjunto de afirmações que são tomadas como verdadeiras pelo investigador. No contexto empírico, por outro lado, a identificação de uma aporia impõe a busca de explicações. Nesse âmbito, o termo aporia relaciona-se ao caso em que as evidências empíricas não se conformam às expectativas do investigador e geram situações que parecem incompreensíveis. Nesse 
caso, a solução deve surgir da busca por explicações para a ocorrência das evidências que geram a dificuldade. ${ }^{73}$

Evidentemente, os critérios para o que conta como uma aporia no contexto dialético são mais restritos (ver Top. VI 6, 145b17-20) do que no contexto empírico Evitarei, no entanto, a discussão acerca de haver ou não de dois sentidos de aporia $^{74}$ e empregarei "Ap 1 " para fazer referência ao uso dialético do termo e "Ap 2 " ao seu uso empírico.

As diferenças entre $A p_{1}$ e $A p_{2}$ estão relacionadas ao grau de autoridade que as evidências coligidas têm em cada contexto. Como já foi notado acima, a despeito do valor que os endoxa tenham como evidência, sua verdade sempre pode ser posta em questão. No caso empírico, por outro lado, as evidências são, em princípio, tomadas como verdadeiras. Como nota Irwin, no entanto (1987, p. 124), mesmo no contexto empírico pode-se concluir que uma evidência é falsa e, com isso, excluí-la do âmbito do que deve ser explicado. De fato, até mesmo no contexto da ciência empírica Aristóteles emprega a distinção entre phainomena de menor e maior autoridade, o que sugere que os últimos são mais resistentes do que os primeiros à exclusão do âmbito do que deve ser explicado. ${ }^{75}$

Minha sugestão é que o processo de diaporein que é mencionado no trecho B de [2] está muito mais próximo de $A p_{2}$ do que de $A p_{1}$. Nesta perspectiva, o procedimento diaporemático de [2] não está baseado na identificação de incompatibilidades entre as afirmações coletadas e a solução da aporia não se dá pela recusa de uma das afirmações conflitantes como falsa. Ao invés disso, o procedimento aponta problemas cuja solução demanda a proposta de uma explicação.

A exposição de aporias em EN VII 2 começa com a expressão aporêseie d'an tis (que pode ser traduzida por "alguém poderia perguntar" ou "alguém poderia apresentar como problema"). Trata-se de expressão muito comum em Aristóteles e seu uso (assim como o de expressões semelhantes) muito frequentemente não está estritamente associado à identificação de incompatibilidades em um conjunto determinado de teses ou opiniões. Com frequência, expressões como essa anunciam a apresentação de problemas ou de situações que causam perplexidade à maneira de Ap 2 . Assim, em EE II 10, 1226a33-35

73 "No caso empírico, o impasse [puzzle] não surge com respeito ao evento que cria o impasse realmente ocorrer; se ele não ocorresse, não haveria impasse. Ao invés disso, o impasse surge acerca de como e por que o evento ocorre, na suposição de que ele realmente ocorre." (Irwin : 1987, p. 123, grifo meu) "Na dialética, por outro lado, a existência de impasses é, ela própria, um desafio à verdade das aparências (id., p. 127, grifo meu).

${ }^{74}$ Ver Owen (1961, p. 87) e Irwin (1987, p. 123-124).

${ }^{75}$ De Caelo 306a16-17; ver Irwin (1987, p. 125). 
Aristóteles emprega a expressão aporêseien an tis para perguntar "por que os médicos deliberam acerca daquilo de que têm ciência e os gramáticos não"? A solução não é dada pela eliminação de uma dentre duas teses conflitantes nem pela adição de qualificações às teses originais. Ao contrário, a resolução do problema é obtida pelo fornecimento de uma explicação: “a causa [aition] disso é porque, sendo de dois modos o erro (pois ou erramos raciocinando ou realizando o próprio ato com base na percepção), na medicina é possível errar dos dois modos, ao passo na gramática só é possível errar com base na percepção e na ação" (1226a35-b1). De mesmo modo, em EE II 1, 1219b16-18, Aristóteles pergunta "por que os bons não são melhores do que os maus durante a metade da vida" (quando dormem)? Tal pergunta é dita ser um aporoumenon e, novamente, a solução não se dá por meio da eliminação de uma tese, mas pelo fornecimento da causa pela qual ocorre o fato que é tido como intrigante: "a causa [aition] disso é porque o sono é uma inação da alma, mas não uma atividade" (1219b19-20). ${ }^{76}$

A primeira questão do conjunto de aporias de EN VII 2 diz respeito ao modo pelo qual alguém age incontinentemente estando de posse de uma crença correta (1145b2122). Trata-se de uma dificuldade que não decorre diretamente de incompatibilidades entre as opiniões listadas até então e que é exposta por referência à opinião socrática segundo a qual não é possível agir contrariamente ao conhecimento (1145b23-24). Pode-se, é claro, sustentar que o conjunto de endoxa considerado é mais amplo do que as opiniões expressamente expostas, incluindo a tese de Sócrates. No entanto, ainda que (como notado acima) o domínio dos endoxa relevantes seja efetivamente mais amplo do que a lista fornecida em EN VII 1, viu-se que há boas razões para excluir desse âmbito a tese socrática. ${ }^{77}$ Tudo considerado, parece mais razoável concluir que Aristóteles está compreendendo o procedimento de expor dificuldades de maneira mais frouxa do que se supõe na interpretação tradicional. Assim, Aristóteles é livre para formular questões sobre o ponto mobilizando tudo o que considere relevante sobre o assunto, mesmo que isso exceda o que ocorre nos phainomena.

\footnotetext{
${ }^{76}$ Ambos exemplos foram retirados da Ética Eudêmia. De fato, o vocabulário relacionado à noção de aporia é muito mais comum na Ética Eudêmia do que na Nicomaqueia. Esse fato é, por vezes, tomado como indício de que os chamados "livros comuns" (EN V, VI e VII), que foram transmitidos como pertencendo conjuntamente a cada uma das duas Éticas, pertenciam originalmente à Eudêmia (ver Cooper : 2009, p. 27).

${ }^{77} \mathrm{O}$ conflito entre os phainomena sobre a incontinência e a concepção socrática da ação dá-se diretamente a partir da tese segundo a qual ninguém age contrariamente ao que considera ser o melhor. Evidentemente, se é impossível agir contrariamente ao que se crê ou considera ser melhor, é também impossível agir contrariamente ao que se sabe ser melhor.
} 
A sugestão segundo a qual o procedimento mencionado no trecho B de [2] busca apontar problemas cuja solução demanda a formulação de uma explicação é compatível com a prática, frequentemente observável em Aristóteles de buscar apoio em suas teses no fato que as pessoas afirmam algo que ele mesmo não aceita como verdadeiro. Em tais casos, a estratégia consiste em mostrar que, sendo a realidade tal como Aristóteles a descreve, é compreensível que se enunciem tais ou quais afirmações imprecisas ou equivocadas a seu respeito. Equívocos quanto a continência e incontinência, por exemplo, são compreensíveis pela semelhança entre a compreensão da noção do "forçado" (bia(i)) que se aplica ao âmbito humano e é corretamente descrita por Aristóteles e a noção do "forçado" que se aplica aos seres inanimados (EE II 8, 1224b2ss.; ver também $1224 \mathrm{~b} 21 \mathrm{ss}$.). Trata-se dos casos que se conformam à diretriz metodológica segundo a qual "tornar manifesto de modo razoável por que parece ser verdadeiro o que não é verdadeiro, produz a crença sobretudo no que é verdadeiro" (EN VII 14, 1154a22-26).

Em tais casos, a evidência relevante corresponde ao fato que as pessoas dizem tais ou quais inverdades. Ainda que suas afirmações sejam falsas, elas são úteis como indícios de um estado de coisas real, uma vez que resultam de uma apreensão míope de tal realidade. A tese de Aristóteles ganha força quando se mostra capaz de explicar o surgimento de tais opiniões.

Nessa proposta, o procedimento diaporemático do trecho B de [2] busca antes identificar o que deve ser explicado - e não tanto o que deve ser mantido como verdadeiro e o que deve ser repelido como falso. Assim, a permanência das opiniões reputadas que é mencionada em $\mathrm{D}$ não corresponde à formação de um conjunto $\Delta_{\mathrm{f}}$ composto apenas por teses que são tomadas como verdadeiras. Ao invés disso, kataleipêtai indica a retenção dos endoxa em um conjunto (digamos $\Delta_{\mathrm{e}}$ ) formado pelas opiniões (verdadeiras ou falsas) cuja ocorrência deve poder ser explicada a partir das teses propostas pelo investigador. Desse modo, kataleipêtai em D indica que as evidências, ou seja, os endoxa, devem ser tanto quanto possível mantidos no conjunto do que a teoria proposta pretende explicar. Assim como no contexto empírico, a exclusão de uma ou outra evidência de $\Delta_{\mathrm{e}}$ não é suficiente para impor a recusa da teoria, mas, novamente, tal como no contexto empírico, o investigador deve tanto quanto possível evitar de excluir evidências, sobretudo no que diz respeito às principais ou de maior autoridade. ${ }^{78}$

${ }^{78}$ Note-se que as teses desenvolvidas por Aristóteles em EN VII 1-10 efetivamente tornam compreensível o surgimento de opiniões que ele toma como endoxa, mas cuja verdade ele recusa. 
Note-se que o texto metodológico EE VII 2, 1235b13-18, que corresponde à passagem [3] discutida acima, pode ser compreendido de maneira semelhante. Como foi notado acima, [3] não só é muito próximo de [2], como parece corroborar a interpretação tradicional. A passagem refere-se a oposições entre as opiniões examinadas e estabelece que o ponto final da investigação se dá com a permanência (menein) das oposições por meio da adoção de qualificações nas opiniões originais. Deve-se ressaltar, no entanto, que o resultado se estabelece "se as opiniões contrárias revelarem-se razoáveis". ${ }^{79}$ Essa condição decisiva mostra que o esforço do investigador não pode estar restrito a desfazer o conflito entre as opiniões, mas deve ser de tal sorte que se torne compreensível por que as diferentes opiniões emergem. Trata-se, portanto, de uma passagem que também é bem compreendida à luz da interpretação sugerida para [2].

Pode-se fazer uma objeção a essa proposta partindo do uso de deiknunai no trecho C de [2]. Nas traduções da passagem metodológica de EN VII 1, esse verbo é normalmente traduzido por "provar". Assim compreendido, o trecho C indica que o procedimento tem por objetivo identificar as opiniões verdadeiras, com vistas à formação de um conjunto $\Delta_{\mathrm{f}}$ nos termos da leitura tradicional. Nessa perspectiva, as opiniões contidas em $\Delta_{\mathrm{f}}$ foram "provadas" porque sua verdade foi estabelecida (ainda que à maneira dialética e não demonstrativa).

O verbo deiknunai, no entanto, frequentemente tem sentido mais amplo do que o de fornecer uma prova em sentido estrito ${ }^{80}$ Diante disso, quero sugerir que seu sentido em [2] não envolve o estabelecimento de uma prova da verdade das opiniões às quais se aplica, ou seja, dos endoxa. Caso revelador a respeito do uso desse termo desvinculado do estabelecimento da verdade de proposições encontra-se na discussão sobre as relações entre a demonstração e a definição em Segundos Analíticos II 7-10. Em 92a34-35, Aristóteles pergunta de que modo quem propõe uma definição poderá deiknunai a essência. Ao longo da discussão, fica claro que não é possível demonstrar (apodeiknunai) a definição, mas que se deve apreendê-la através da demonstração (ver 93b15-20). Tomemos como exemplo a definição de trovão como "estrondo nas nuvens ocasionado pelo apagar do fogo". Nesse caso, há uma demonstração cuja conclusão corresponde à

Comparar, por exemplo, i) EN VII 1, 1145b16-17 com EN VII 3, 1146b19-22; ii) EN VII 1, 1145b19-20 com EN VII 4, 1147b20-30 e iii) EN VII 1, 1145b17-19 com EN VII 10, 1152a6-15.

${ }^{79}$ ean eulogôs phainêtai ta enantia dokounta: $1235 \mathrm{~b} 15$

${ }^{80}$ A esse respeito, o termo contrasta com apodeiknunai. Ver o verbete deiknunai no Index de Bonitz. 
ocorrência do estrondo nas nuvens e cujo termo médio corresponde ao apagar do fogo. ${ }^{81}$ Por meio de tal demonstração, fica silogisticamente estabelecida a verdade da conclusão, ou seja, da ocorrência do estrondo nas nuvens. A definição do trovão, no entanto, deve mencionar a causa do estrondo (o apagar do fogo), que corresponde a seu elemento explicativo fundamental. Tal elemento não ocorre na conclusão da demonstração, mas em seu termo médio, de modo que a verdade da definição tomada em sua totalidade não é estabelecida pelo procedimento demonstrativo. A definição, no entanto, é apreendida contemplando-se a demonstração como um todo, uma vez que nela fíca explícito o vínculo explicativo que ocorre entre o item que ocupa o termo médio (o apagar do fogo) e o item que está na conclusão (o estrondo nas nuvens). Assim, ainda que a demonstração não estabeleça a verdade da definição do trovão, ela a exibe de modo a tornar manifesto seu traço explicativo fundamental.

Se a apreensão da definição que está associada à demonstração corresponde ao deiknunai com o qual Aristóteles abre a discussão em Seg. An. II 7, então o termo parece estar sendo empregado de modo que está mais próximo de seu sentido ordinário de "mostrar" do que do sentido técnico de "provar". Afinal, a definição do trovão revela-se na demonstração, mas não é provada por ela.

Para a compreensão do deiknunai que ocorre na porção C de [2], quero propor que se retenha o aspecto negativo do exame do uso do termo em Seg. An. II 7. Tal como naquela discussão, seu uso em [2] não indica que o procedimento busca estabelecer a verdade dos endoxa. Desse modo, é possível interpretá-lo em consonância com a sugestão feita acima acerca do sentido relevante de aporia e da formação do conjunto $\Delta_{\mathrm{e}}$. Deiknunai panta ta endoxa, em 1145b4-5, não corresponderia ao estabelecimento da verdade dos endoxa, mas à sua "prova" em um sentido mais fraco, ou seja, o de prover uma explicação para a ocorrências daquelas opiniões. Para evitar a associação quase imediata que o termo "prova" tem com o estabelecimento da verdade de uma proposição e na falta de alternativa mais adequada, proponho traduzir deiknunai em $1145 \mathrm{~b} 4$ por "explicar". ${ }^{82}$

81 i) Estrondo atribui-se ao apagar do fogo. ii) $\mathrm{O}$ apagar do fogo atribui-se a nuvem. Logo: iii) Estrondo atribui-se a nuvem. Ver 93b7-14.

${ }^{82}$ Ver o item 3 do vocábulo deiknumi de Liddell, Scott, Jones [1843] 1996. Uma alternativa que evita o termo "provar" encontra-se na tradução de [2] proposta por Broadie/Rowe, que retém o sentido primário de deiknunai: "having first raised the problems, thus display, if we can, all the views people hold...". O correspondente português "mostrar", no entanto, parece excessivamente fraco para o contexto. 
Assim, o ponto final da investigação corresponderá ao estabelecimento de uma teoria que é capaz de explicar as opiniões reputáveis que contam como phainomena no contexto - se não todas, necessariamente a maioria e as principais dentre elas. A teoria bem sucedida deverá ser capaz de solucionar as dificuldades (luêtai ta duscherê em D) que foram identificadas no exame dos problemas (diaporêsantas em B) ou seja, tornar compreensível o que parece surpreendente nas evidências coletadas (C). Se a teoria proposta for capaz de prover as explicações necessárias sem excluir do seu explanandum os endoxa, o ponto terá sido suficientemente estabelecido (dedeigmenon an eiê hikanôs em E).

Os intérpretes frequentemente notam que o procedimento extraído de [2] pela interpretação tradicional aplicam-se apenas de maneira vaga nas obras de Aristóteles. A esse respeito, a interpretação proposta tem a vantagem de encontrar em [2] um conjunto de diretrizes menos restritivas que, desse modo, casam melhor com a prática de Aristóteles. Nesta interpretação, [2] não impõe ao investigador a tarefa de buscar meios pelos quais se possa, tanto quanto possível, tomar como verdadeiros os endoxa. O objetivo do procedimento, ao invés disso, seria o de tornar compreensíveis os endoxa, quer sejam tomados como verdadeiros, quer como falsos. Isso alarga consideravelmente o domínio de possibilidades pelas quais a teoria desenvolvida pelo investigador pode relacionar-se com os endoxa. Nesta perspectiva, não é surpreendente que Aristóteles pareça dar mais importância às suas próprias teses do que aos endoxa. Ao contrário, isso se torna perfeitamente coerente com o método.

\section{Conclusão}

Nas páginas anteriores, busquei discutir uma interpretação que há várias décadas tem sido predominante a respeito do método da ética aristotélica. Trata-se de uma interpretação que encontra na dialética a principal fonte do método de Aristóteles para a filosofia prática. Como procurei mostrar, as origens dessa linha de interpretação estão assentadas na proposta de buscar nos Tópicos o marco metodológico para a ética de Aristóteles. No entanto, ao menos a partir da publicação do texto de Owen, é a passagem metodológica de EN VII 1 que passa a ocupar o foco dessa interpretação. A despeito da relação com os Tópicos ter em certa medida ficado menos marcada nas discussões sobre o método, a interpretação seguia encontrando uma concepção "dialética" do método. De fato, o modo como a interpretação tradicional compreende o papel dos endoxa e das 
aporias em [2] torna o procedimento lá apresentado reminiscente da argumentação dialética que é discutida nos Tópicos.

A interpretação que foi aqui proposta para o procedimento exposto no texto [2] diverge da tradicional sobretudo com respeito à compreensão do papel dos endoxa e das aporias. Com isso, não se aplicam ao texto compreendido nesta interpretação as razões que, na leitura tradicional, justificavam que o procedimento fosse qualificado de "dialético". Isso, evidentemente, não significa que outros procedimentos que possam ser tomados como dialéticos não tenham papel no método da ética aristotélica. Se a intepretação aqui proposta estiver correta, no entanto, a passagem que foi tomada como texto decisivo para a caracterização do método da ética como sendo fundamentalmente de natureza dialética não pode fornecer apoio a tal conclusão.

Raphael Zillig

Universidade Federal do Rio Grande do Sul

\section{Bibliografia}

Allan, D. J. (ed.) Aristotelis - De Caelo. Oxford, Clarendon, 1936.

Barnes, Jonathan. (ed.) The complete works of Aristotle - The revised oxford translation. Princeton, Princeton University Press, 1984.

Barnes, Jonathan. "Aristotle and the methods of ethics". Revue Internationale de Philosophie, 34, 1980, p. 490-511.

Barnes, Jonathan. Posterior Analytics. Oxford, Clarendon Press, [1975] 1993.

Berti, E. “O uso ‘científico' da dialética em Aristóteles”. [trad. Verçosa Filho, E. G.] In: Berti, E. Novos estudos aristotélicos I - Epistemologia, lógica e dialética. São Paulo, Loyola, 2010. Originalmente publicado em Giornale di Metafisica. Vol. 17, n. 1, 1995, p. 169-190.

Bolton, R. "The epistemological basis of aristotelian dialectic". In: SIM, M. From puzzles to principles? Lanham, Lexington, 1999. Originalmente publicado em Devereux, D.; Pellegrin, P. Biologie, logique et métaphysique chez Aristote. Paris, CNRS, 1990.

Bonitz, H. Index Aristotelicus. Berlin, Walter de Gruyter, [1870] 1961. https://doi.org/10.1515/ 9783110852332

Bostock, D. Aristotle's Ethics. Oxford, Oxford U. P. 2000.

Bronstein, D. Aristotle on knowledge and learning. Oxford, Oxford U. P. 2016. https://doi.org/ 10.1093/acprof:oso/9780198724902.001.0001

Brunschwig, J. Aristote Topiques (Livres I-IV). Paris, Les Belles Lettres, 1967. 
Brunschwig, J. Aristote Topiques (Livres V-VIII). Paris, Les Belles Lettres, 2007.

Burnet, J. The ethics of Aristotle. London, Methuen, 1900.

Burnyeat, M. "Good repute". London review of books. vol. 8, n. 19, 1986, pp. 11-12.

Bywater, I. (ed.) Aristotelis - Ethica Niomachea. Oxford, Clarendon, 1894.

Cleary, J. "Phainomena in Aristotle's methodology. International Journal of Philosophical Studies, vol. 2, n. 1, 1994. https://doi.org/10.1080/09672559408570784

Cooper, J. M. "Nicomachean Ethics VII 1-2. In Natali, C. Aristotle: Nicomachean Ethics, Book VII. Oxford, Oxford U. P. 2009.

Cooper, J. M. Reason and human good in Aristotle. Indianapolis, Hackett,1986.

Crisp, R. (trad.) Aristotle Nicomachean Ethics. Cambridge, Cambridge U. P.2004.

Crisp, R. “Aristotle on dialectic”. Philosophy, n. 66, 1991, p. 522-524.

Denyer, N. Language, thought and falsehood in ancient greek philosophy. London, Routledge, 1991.

Devereux, D. "Scientific and ethical methods in Aristotle's Eudemian and Nicomachean Ethics." In: Henry, D.; Nielsen, K. M. Bridging the gap between Aristotle's science and ethics. Cambridge, Cambridge U. P. 2015. https://doi.org/10.1017/CBO9780511846397.008

Dirlmeier, F. Aristoteles - Eudemische Ethik. Berlin, Akademie Verlag, [1963] 1984. https://doi.org/10.1524/9783050048741

Frede, D. "The endoxon mystique: what endoxa are and what they are not". Oxford Studies in Ancient Philosophy, vol. 43, 2012, p. 185-215. https://doi.org/10.1093/acprof:oso/9780199666 164.003.0007

Greenwood, L. H. G. Aristotle Nicomachean Ethics - Book Six. Cambridge, Cambridge U. P. 1909.

Grote, G. Aristotle. Vol. 1. London, John Murray, 1872.

Hamelin, O. Le système d'Aristote. Paris, Librairie Félix Alcan, 1920.

Hardie, W. F. R. Aristotle's ethical theory. Oxford, Clarendon, 1980. https://doi.org/10.1093/ acprof:oso/9780198246329.001.0001

Haskins, E. "Endoxa, epistemological optimism, and Aristotle's rhetorical project". Philosophy \& Rhetoric. vol. 37, n. 1, 2004, p. 1-20. https://doi.org/10.1353/par.2004.0010

https://doi.org/10.1007/BF01064006

Hussain, M. "For dialectic puts questions about matters which philosophy knows". In SIM, M. From puzzles to principles? Lanham, Lexington, 1999.

Irwin, T. (trad.) Nicomachean Ethics - Translated with introduction, notes and glossary by Terence Irwin. 2 ed. Indianapolis, Hackett, 1999.

Irwin, T. "Ways to first principles: Aristotle's methods of discovery". Philosophical Topics, vol. XV, n. 2, 1987.

Irwin, T. Aristotle's first principles. Oxford, Clarendon, 1988.

Joachim, H. H. (ed.) Aristotle on coming-to-be and passing away. Oxford, Clarendon, 1926.

Johansen, T. "Myth and logos in Aristotle". In: BUXTON, R. From myth to reason. Oxford, Oxford U. P. 1999.

Karbowski, J. "Endoxa, facts, and the starting points of the Nicomachean Ethics". In HENRY, D.; NIELSEN, K. M. Bridging the gap between Aristotle's science and ethics. Cambridge, Cambridge U. P. 2015b. https://doi.org/10.1017/CBO9780511846397.007 
Karbowski, J. "Phainomena as witnesses and examples: the methodology of Eudemian Ethics I 6. Oxford Studies in Ancient Philosophy, vol. 49, 2015a, p. 193-226.

Kraut, R. "How to justify ethical propositions: Aristotle's method". In Kraut. The Blackwell guide to Aristotle's Nicomachean Ethics. Malden, Blackwell, 2006. https://doi.org/10.1002/ 9780470776513

May, H. Aristotle's ethics. London, Continuum, 2010.

Mckirahan, R. Principles and proofs. Princeton, Princeton U. P. 1992.

Moraux, P. "La joute dialectique d'après le huitième livre des Topiques. In: Owen, G. E. L. Aristotle on dialectic - The Topics. Oxford, Clarendon, 1968.

Natali, C. "Posterior Analytics and the definition of happiness in NE I". Phronesis 55, 2010, p. 304-324. https://doi.org/10.1163/156852810X523905

Natali, C. "Rhetorical and scientific aspects of Nicomachean Ethics". Phronesis 52, 2007, p. $364-$ 381. https://doi.org/10.1163/156852807X229258

Nussbaum, M. The Fragility of Goodness. Cambridge, Cambridge U. P. 1986. https://doi.org/ $10.1017 / \mathrm{cbo} 9780511817915$

Owen, G. E. L. "Tithenai ta phainomena". In MANSION, S. Aristote et les problèmes de méthode. Louvain, Publications Universitaires de Louvain, 1961.

Pakaluk, M. Aristotle's Nicomachean Ethics - an introduction. Cambridge, Cambridge U. P. 2005. https://doi.org/10.1017/CBO9780511802041

Peck, A. L. (ed.; trad.) Aristotle - Historia Animalium. Cambridge, Harvard U. P. 1991.

Pereira, Oswaldo Porchat. "Voltando à dialética de Aristóteles". Analytica, v. 8, n. 1, 2004, p. 143-188.

Pereira, Oswaldo Porchat. Ciência e dialética em Aristóteles. São Paulo, Editora UNESP, 2000.

Pritzl, K. "Opinions as appearances: endoxa in Aristotle". Ancient Philosophy, n. 14, 1994, p. 4150.

Reeve, C. D. C. Practices of reason. Oxford, Oxford U. P. 1992.

Ross, W. D. (ed.) Aristotelis Ars Rhetorica. Oxford, Clarendon, 1959.

Ross, W. D. (ed.) Aristotelis De Anima. Oxford, Clarendon, 1956.

Ross, W. D. (ed.) Aristotelis Politica. Oxford, Clarendon, 1957.

Ross, W. D. (ed.) Aristotelis Topica et Sophistici Elenchi. Oxford, Clarendon Press, 1958.

Ross, W. D. (ed.) Aristotle's Metaphysics - A revised text with introduction and commentary by W. D. Ross. Oxford, Clarendon, 1924.

Ross, W. D. (ed.) Aristotle's Physics. Oxford, Clarendon, 1936.

Ross, W. D. (ed.) Aristotle's Prior and Posterior Analytics. Oxford, Clarendon, 1949.

Ross, W. D. (trad.) "Ethica Nicomachea". In Ross, W. D. The works of Aristotle, V. IX, Oxford, Clarendon, 1925.

Ross, W. D. (trad.) Brown, L. (rev.) The Nicomachean Ethics - Translated by David Ross, revised with an introduction and notes by Lesley Brown. Oxford, Oxford U. P. 2009.

Ross, W. D. (trad.) Metaphysica. Oxford, Clarendon, 1908.

Ross, W. D. Aristotle. London, Routledge, [1923] 1995.

Salmieri, G. "Aristotle's Non-'Dialectical' Methodology in the Nicomachean Ethics. Ancient Philosophy, vol. 29, 2009, p. 311-335. https://doi.org/10.5840/ancientphil200929228 
Sim, M. “Introduction”. In: Sim. (ed.) From puzzles to principles? Lanham, Lexington, 1999.

Slomkowski, P. Aristotle's Topics. Leiden, Brill, 1997. https://doi.org/10.1163/9789004320994

Slomkowski, P. Review of Smith, R. Aristotle: Topics: Books I and VIII. The Classical Review. v. 49/01, 1999, p. 23-25.

Smith, R. "Aristotle on the uses of dialectic". Synthese 96, 1993, p. 335-358.

Smith, R. "Dialectic and method in Aristotle". In: SIM, M. From puzzles to principles? Lanham, Lexington, 1999.

Smith, R. Aristotle Topics - Books I and VIII. Oxford, Oxford U. P. 1997.

Stewart, J. A. Notes on the Nicomachean Ethics of Aristotle. Oxford, Clarendon, 1892.

Wallies, M. (ed.) Alexandri Aphrodisiensis - In Aristotelis Topicorum Libri Octo Commentaria. Berlin, Reimer, 1891.

Walzer, R. R.; Mingay, J. M. (ed.) Aristotelis - Ethica Eudemia. Oxford, Clarendon, 1991.

Zingano, M. "Acrasia e o método da ética". In: Zingano. Estudos de ética antiga. São Paulo, Discurso Editorial, 2007.

Zingano, M. "Dialética, indução e inteligência na aquisição dos primeiros princípios. Analytica, v. 8 , n. 1, 2004, p. 27-41.

Zuppolini, B. Ontological underpinnings of Aristotle's philosophy of science. Tese de doutoramento. Universidade Estadual de Campinas, 2017. 